\title{
III The Core of the Network: Friends of Blood and Marriage
}

In modern societies, kinship and marriage might be considered weak factors in establishing economic cooperation among individuals. In medieval Florence, though, blood ties as the building blocks of business firms are well-illustrated by the case of companies founded by potential families (consorterie) like the Alberti and the Peruzzi at the beginning of the fourteenth century. ${ }^{1}$

Richard A. Goldthwaite claims that the role of kinship relations in the formation of business firms had considerably weakened by the early fifteenth century. ${ }^{2}$ The sizeable fourteenth-century firms, which lasted through several generations, were replaced by partnerships that survived only for a couple of years, while their partners invested simultaneously into other companies as well. The phenomenon should have been closely related to the changing practices in inheritance strategies, altering the inpartible properties with the division of patrimony.

However, the importance of in-law ties in the formation of smaller business partnerships and networks has never been widely studied. As the example of the Scolaris shows, their in-laws and the in-laws' in-laws grew into the most significant social units of their business network, a pattern which might have characterized trade networks throughout the period. The consorteria, that is, the kinship network as well as the parentado, the network of in-laws, occupied a central role in the Scolaris' success in the Kingdom of Hungary as well as in their involvement in the Florentine economy.

In the city statutes of 1415 , the consorteria was described as a unity composed of 'consortes sint de eadem stirpe per lineam masculinam etiam superios usque in infinitum', that is, a patrilineal lineage. ${ }^{3}$ That the Scolari

1 Sapori, I libri di commercio dei Peruzzi. Goldthwaite and Settesoldi and Spallanzani, Due libri mastri degli Alberti. Boschetto, 'Leon Battista Alberti e Firenze'.

2 Goldthwaite, The Economy of Renaissance Florence, pp. 64-77.

3 Per il significato del termine consorteria vedi lo Statuto del Comune di Firenze del 1415: 'De compromissis fiendis inter consortes. Si aliqua quaestio, differentia vel controversia oriretur vel esset inter patrem vel matrem et filium vel filiam fratres vel sorores carnales vel uterinos vel uterinas patruum nepotem vel neptem vel alios consanguineos coniunctos seu consortes qui consortes sint de eadem stirpe per lineam masculinam etiam superios usque in infinitum.' Statuta populi et communis Florentiae, Liber II, Rubrica LXVI. According to Kent, the consorteria ‘[...] Kent, Household and Lineage, p. 6. 
still at the beginning of the fifteenth century were thinking in terms of their own consorteria is highlighted by a short reference found in Andrea Scolari's correspondence, in describing one of his brothers as 'nostri consors de Scolaribus.' ${ }^{4}$ The consorteria, in another sense, was also an economic unit of which members owned immovable properties jointly. ${ }^{5}$ In the Scolaris' case, the castle of Ozora was a shared property between the two Scolari brothers and their nephew, Leonardo di Caccia Altoviti. The studies of Francis W. Kent and Lauro Martines, among others, have pointed out that the consorterie might have also been extended to the female line, which might explain why their nephew, son of their sister, became their divisional kinsman. ${ }^{6}$ Members of the consorterie patronized religious places together and their unity very often was formalized even by a notary act. ${ }^{7}$

The parentado, that is, the matrilineal extension of the consorteria, was based on marriage alliances between in-law families. Anthony Molho's analysis of marriage strategies of the Florentine elite has revealed the high endogamy that characterized nuptial ties in merchant families throughout the period. The importance of such family bonds is clearly underlined by the employment of marriage brokers, whose role was to find the perfect match for their commissioner's offspring. ${ }^{8}$ The Scolari probably also relied on such intermediaries when trying to marry off their female relatives. ${ }^{9}$

4 Andrea mentioned his late brother, Bernardo, in this way. ASF, Corp. Rel. Sopp. 78. 326 . fol. $324 \mathrm{r}$.

5 Kent, Household and Lineage, 1977, p. 121.

6 'Drawing upon a strong sense of clan and consanguinity, noblemen clustered into tight-knit associations and built fortified towers so as to defend themselves or to expand their rights and privileges. Each such consorteria was a sworn corporate grouping, consisting of males descended from a common male ancestor. It was therefore a male lineage, although, when extinction threatened, the line might be transferred via a woman. In time the consorteria entered into sworn association with other like neighbourhood groups.' Martines, Power and Imagination, pp. 35, 37. See also: Lansing, The Florentine Magnates, p. 30.

7 Consorterie were sometimes so formally structured that members of the family needed to supplicate to the Signoria for liberating them from their consorteria ties, as for example in the case of Piuvichese Brancacci, in 1374. Pandimiglio, Felice di Michele vir clarissimus e una consorteria, p. 14. See also the case of the heirs of messer Giovanni di ser Ristoro, who died in 1414. Tognetti, Da Figline a Firenze, pp.45-53.

8 See the example of the marriage between Marco Parenti and Caterina Strozzi. Musacchio, Art, Marriage and Family, p.2.

9 See the example of Giovanni di ser Cacciotto Cacciotti, a marriage broker, who was probably employed by Andrea Scolari to find a husband for his niece. ASF, Corp. Rel. Sopp. 78. 326. fol. 288r. See also Giovanni's tax declaration, submitted in 1427 , in which he cites the money he expected from the Scolari for his service: ASF, Catasto 15. fol. 841r. For the fragments of Giovanni's account book, referring to certain marriages he facilitated see: ASF Carte Strozziane II. 76 . fols. $648 \mathrm{r}-649 \mathrm{v}$. 
Among the families studied in this chapter, four - the Albizzi, the Altoviti, the Infangati, and the Guadagni - were bound to the Scolari by marriage ties. Though the marriage between the Albizzi and the Scolari was never celebrated, according to Florentine customs, as soon as the marriage agreement took place and the negotiations about the dowry were set, the two families regarded each other as future in-laws.

The present chapter also includes a discussion of four families that probably did not share any blood or marriage ties with the Scolari, but were intimately connected to members of their inner circle. Among them, the Del Bene and the Cavalcanti were bound by marriage ties to the Da Montebuoni. Two other families, the Borghini and the Della Rena, had an even more distant place in the Scolaris' network; the Borghini were in-laws of the Cavalcanti, and the Della Rena figured as in-laws of the Infangati. Yet, their intimate connections to the Scolari reflect upon the significance of such ties in business and social life.

\section{The Buondelmonti/Da Montebuoni Family}

Up to the thirteenth century, the Scolari belonged to the Buondelmontis' consorteria. ${ }^{10}$ Since the eleventh century, their estates were concentrated at the nearby Abbey of Passignano in the Chianti area, where their earliest base was the castle of Montebuoni. By the twelfth century, the Buondelmonti lineage turned into the leading patron of the parish church of Santa Maria Impruneta, which they developed into the most significant place of pilgrimage in the Florentine countryside. ${ }^{11}$ Its miraculous icon of the Virgin Mary gained such popularity that it was brought to Florence every year on the day of the Nativity in a procession, which went from Impruneta to the Santissima Annunziata Church. ${ }^{12}$ By the reputation of its precious relic, the incomes of the parish grew exponentially, which the Buondemonti, as the ones also electing priests to the parish, enjoyed for centuries. ${ }^{13}$ Until the beginning of the fourteenth century, the Scolari, as descendants of the lineage, were among those electing the parish priest. ${ }^{14}$ The ancient patronage and the

Bizzocchi, 'La dissoluzione di un clan familiare'.

11 Herlihy, 'Santa Maria Impruneta', Pinto, 'L'Impruneta e Firenze', Ibid., 'L'Impruneta' Ibid.,

'Toscana medievale'.

12 Priorista, p. 189.

13 For a more general overview of the history of the settlement see: Impruneta, una pieve, un paese.

14 Bizzocchi, 'Patronato dei Buondelmonti sulla pieve dell'Impruneta', p. 128. 
prestige of Imprunta might have inspired even Pippo Scolari himself to donate a votive cross to the church. ${ }^{15}$

The Buondelmonti, unlike the Scolari, were of Guelph loyalties, so they did retain their urban properties, including the family tower located just next to the palace of the Guelph Party, constucted at the beginning of the fifteenth century. Several of them even served as captains of the party and took an active part in the confiscation of the Scolaris' properties. However, those branches that did not give up their magnate status were also subject to the confiscations. ${ }^{16}$ In 1378 , the Estimo officials registered eighteen households of the lineage, who lived overwhelmingly in the gonfalon Vipera quarter of Santa Maria Novella. ${ }^{17}$ Thanks to the fact that some of these branches applied for popolani status, the ${ }_{1433}$ Catasto contains ten Buondelmonti households and six Da Montebuoni households. ${ }^{18}$ While the Buondelmonti households were dispersed in various parts of the city, the Da Montebuoni households, instead, were in the gonfalon of Vipera, Quarter of Santa Maria Novella. ${ }^{19}$

The Buodelmonti households reported 39 family members, and they had 5837 florins of total assets. Four did not possess any taxable assets and one was listed as miserabile. The Da Montebuoni counted 66 family members and they declared 1059 florins of total assets. But in their case, four of them paid only composto and one household did not pay at all, which shows their unbalanced financial situation.

In the fourteenth century, the Buondelmonti and the Scolari still owned properties nearby each other in the Florentine countryside, an indication of their former social and economic integrity ${ }^{20}$ This left a strong impact on the historical memory of the family. By the end of the fourteenth century, one of the popolani branches, headed by Andrea di messer Lorenzo, had already

15 Tarchi, 'Una lettera di Maria Maddalena d'Austria'.

16 See the case of Giovanni d'Agnolo Buondelmonti, in 1380. ASF, Capitani di Parte Guelfa, Numeri Rossi 52 . fol. 85 r.

17 They were very extended, but by 1378 , they counted only eighteen households, mainly located in the gonfalon of 31, with the one exception of Ghino di Manente's household, which lived in the Via San Ambrogio, gonfalon of Chiavi. ASF, Prestanze 369. fol. 95r. All mentioned as Buondelmonti.

18 Da Montebuoni: Francesco di Teghiaio. ASF, Catasto 449. fol. 268r; Alessandro di Teghiaio. Catasto 455. fol. 23r; Lorenzo di messer Gherardo. Catasto 455. fol. 263 r; Simone di messer Andrea. Catasto 455. fol. 478r; Sandro di Pepo. Catasto 455. fol. 484r; Simone d'Andrea. Catasto 455 . fol. 5oor.

19 The Buondelmonti households were located in the gonfalon of Vipera, quarter of Santa Maria Novella, gonfalon of Chiavi, Quarter of San Giovanni, gonfalons of Nicchio and Drago, quarter of Santo Spirito, gonfalon of Drago, and gonfalon of Carro, quarter of Santa Croce.

20 The notary registers of Giovanni Pacini provide an eloquent example for this phenomenon, being filled with cases of the Buondelmonti and of the Scolari. ASF, NA, 15880. 
established a connection with the Kingdom of Hungary. In 1396, he led the earliest Florentine contingent sent to Sigismund of Luxembourg following his coronation as King of Hungary. Andrea had been made popolani in 1393, which enabled him to run for city offices as well as to serve the Signoria in diplomatic capacities. ${ }^{21} \mathrm{He}$ was an active politician, a frequent speaker of the secret councils. ${ }^{22}$ In 1401, he served the Signoria as head of a diplomatic contingent sent to the pope; later, he also led an embassy to Ladislaus of Durazzo. ${ }^{23}$ In 1410, making his testament, he did not fail to mention that he was heading abroad to take care of some business. ${ }^{24}$

\section{Giovanni di messer Andrea da Montebuoni: The Archbishop (1390-1447)}

In that year, it is possible that Andrea's businesses brought him back to Hungary, when his son, aged 20, appeared for the first time in Hungarian sources as the newly appointed abbot of the Benedictine monastery in Pécsvárad. Given his young age for such an office, we suspect that his nomination was facilitated by Andrea's connections. Previously, Giovanni was living as a Benedictine monk in the Abbey of Praglia, bishopric of Padua. ${ }^{25} \mathrm{He}$ most probably studied law at the University of Padua, where he later served several times as witness of the exams. ${ }^{26}$ In 1410, Pippo Scolari made an official visit to Bologna to negotiate with Pope John XXIII on Sigismund's behalf. In fact, Giovanni's vow, which also included obedience to Pope John XXIII, took place in September 1410 upon Pippo Scolari's return from his embassy. ${ }^{27}$

The abbotship at the monastery of Pécsvárad, a place of authentication (loca credibilia) nearby the prestigious bishopric of Pécs, should have been considered as a good start for the church career of the young Giovanni, who remained there for fifteen years. In 1420, Pope Martin V expressed his support for the young prelate by addressing two recommendations on his behalf to Hungary, one to the King and another to Pippo Scolari. ${ }^{28} \mathrm{He}$ left the Abbey

\footnotetext{
21 He was made popolano on 30 November 1393. Litta and Passerini, I Buondelmonti.

22 Andrea died before 1420. His sons and heirs made a deposit in his name. ASF, Mercanzia 11779. fol. 59 v. He frequently served the Signoria as ambassador. ASF, Signori, Legazioni e commissarie 1. fol. $113 \mathrm{v}$.

23 ASF, Signori, Rapporti e relazioni di oratori fiorentini 1. fols. 12v, 38v.

24 For his will, see: ASF, Diplomatico, Normali 29/o9/1410.

25 Archivio Segreto Vaticano, Registri Lateranensi 142. fols. 251r-252r. (12/og/1410), ASF, Diplomatico, Normali, Rinuccini, 12/o9/1410.; Published: Zsigmondkori oklevéltár, II. doc. 7914. 26 Veress, Olasz egyetemeken, p.153. (in 1411)

27 For his vow, see: ASF, Diplomatico, Normali, Rinuccini, 12/og/1410.

28 ASF, Diplomatico, Normali, Rinuccini 13/01/1420; Mellini, Vita di Filippo Scolari, pp. 51, 52.
} 
in 1425, when the Pope nominated him to the position of Archbishop of Kalocsa. He would have thanked the baron himself for his new appointment, who in the preceding three years had been governing the archbishopric. ${ }^{29}$

In the beginning, Giovanni might have relied much on his benefactor's help. But following Pippo's death, gradually he grew into the most powerful member of the Florentine community and he was in the position to help his relatives as well. His nuclear family, composed of his three brothers, developed connections to the papal court. Between 1412 and 1414, one of them, named Simone (b. c. 1387-), appeared as John XXIII's legate in Hungary. ${ }^{30}$ In 1428 , Pope Martin V conferred upon him the title of senator of Rome. ${ }^{31}$ Earlier, another of the brothers, Lorenzo (b.c. 1392-), completed a diplomatic mission for Martin V. ${ }^{32}$ They also built fruitful relations in Sigismund's court in Buda; in 1426 Simone became member of the King's familia. ${ }^{33}$ Their third brother, Niccolò, even settled in the kingdom and integrated into the local society, by marrying a noblewoman, the daughter of Miklós Treutel. ${ }^{34}$ Following his nomination, Giovanni's influence and power, as member of the aula regis, enabled him to defend his relatives also in serious matters, such as business misconduct. ${ }^{35}$ This is clearly exemplified by his nephew, Gianozzo di Giovanni Cavalcanti's case, who, as we shall see later, was hiding from the effects of Sigismund's anger in the archbishopric. Like Andrea Scolari, Giovanni was also eager to provide financial help to members of his extended family who sojourned for certain periods in his court in Kalocsa. ${ }^{36}$

29 Engel, Archontológia, I. 65.

$3^{0}$ For the publication of the corresponding entries in the Registri Vaticani, Archivio Segreto Vaticano see: Zsigmondkori oklevéltár, III. doc. 2139. (15/05/1412); Zsigmondkori oklevéltár, IV. doc. 2301. (26/o7/1414) For the original see: ASF, Diplomatico, Normali, Rinuccini, 26/07/1412, Simone and Lorenzo served Pope John XXIII and Martin V several times as legates. ASF, Diplomatico, Normali, Rinuccini, 24/03/1421; Diplomatico, Normali, Rinuccini, 07/08/1415 (This last document is registered under the wrong date: $25 / 07 / 1415)$ He was also legate in 1421: Diplomatico, Normali, Rinuccini, 24/03/1421. For Simone, see: Archivio Segreto Vaticano, Registri Vaticani 346. fol. 155r. (1414) For the numerous documents regarding the lives of messer Andrea da Montebuoni's sons see: Diplomatico, Normali, Rinuccini.

31 Simple copy of the privilege, made on 16 January 1428. ASF, Diplomatico, Normali, Rinuccini $05 / 02 / 1427$.

32 For Lorenzo's service to Pope Martin V, see: ASF, Diplomatico, Normali, Rinuccini, 05/04/1428.

33 ASF, Diplomatico, Normali, Rinuccini 17/02/1426.

34 Arany, 'Apák, fiúk, fivérek, üzleti partnerek', p. 181.

35 In 1427 , he obtained from the Pope the approval to issue a testament. ASF, Diplomatico, Normali, Rinuccini, 05/02/1427.

36 He provided his relatives with credit. We find him among the creditors of Amerigo e Baldassare di messer Albertaccio and Jacopo di Filippo del Bene. ASF, Catasto 450. fol. 4r. The 
He had also three distant cousins, who were sons of Gherardo da Montebuoni. Among them, Manente (b. c.1392) obtained the canonic of Varadinum in $1426 .{ }^{37}$ Meanwhile, Lorenzo (b. c. 1383) and Gherardo (b. c. 1396) already by 1413 were trading in Hungary, but they returned to Florence following the Scolaris' deaths. ${ }^{38}$

Giovanni da Montebuoni enjoyed his office uninterrupted for ten years, until 1435, when the Count of Cili captured him. ${ }^{39}$ Following his liberation

ambassador Piero di messer Luigi Guicciardini was also indebted to the Archbishop. ASF, Catasto 335. fol. 579v. He might have even served as guarantor for his brother Niccolò in business life. ASF, Guadagni 14. 10. fols. 1r-2v.

37 He was previously the rector of the Sant'Alessandro church in Giogoli (today Scandicci), patronized by the Buondelmonti. See: ASF, Diplomatico, Normali, Rinuccini, 22/o9/1426. For the Buondelmonti in the Kingdom of Hungary, see: Prajda, 'The Florentine Scolari Family'.

$3^{8}$ Lorenzo, who lived for many years in Hungary, worked in close cooperation with Andrea Scolari. Andrea Scolari gave a credit of 500 Florentine florins to Lorenzo, which he was obliged to give back; however, Pippo Scolari, as heir of the Bishop, partly released him from his payment obligations. See the brothers' declaration from 1427: 'E più à uno debito Lorenzo in suo nome proprio colle heredi del messer lo veschovo degli Scholari, chef u veschovo di Valadino fiorini 500. I quali è più anni gli presto al decto Lorenzo dice con questi parti che è sia tenuto rendere e restituire i decti fiorini 500 allui proprio a suo procuratore o rede dal dì gli sono chiesti a sei mesi si veramente si veramente premise Francesco di messer Alessandro de Bardi per me che dove io non restituissi alla sua richiesta o di procuratore o di procuratore o rede il farebbe egli di suo proprio e così aparisce per una scritta s'ò scripta di mano di Francesco sopradecto e di me Lorenzo. La quale scripta ricevette il procuratore del decto vescovo e io aparisco creditore de decti fiorini 500 per libri del decto Francesco e di Bardo suo figliuolo vero. E dice nella partita non siamo pagati i decti denari sanza la loro licentia. Di poi seghui che il decto messer lo vescovo morì e lasciò sua rede dopo certi legati fece in suo testament messer Filippo Spano degli Scolari di che io andai a lui in Ungaria del mese d'octobre passato e del mese di dicembre in Lippa. Il detto messer Filippo mi donò di detta somma di fiorini 500 a me Lorenzo, fiorini 300 il resto volle pagasse per tucto agosto prossimo che viene a certi suoi consorti a cui fece donagione di detta redità di messer lo veschovo e di questo aparisce una scripta di volunta del decto messer Filippo di mano di Ricoldo di ser Pauolo che allora si trovò in decti paesi s'à scripta di mano della heredità cioè di suoi consorti detti e di me Lorenzo opure non ne seghuito conclusione però non so come la cosa seghuirà, abiate buono righuardo.' ASF, Catasto 297. fol. 53v. Gherardo was inprisoned with Antonio di Piero di Fronte. Zsigmondkori oklevéltár, IV. doc.730. In 1427, Lorenzo mentioned in his declaration that he had just returned from Hungary and did not even have a place to stay in Florence, because it had been a long time since he lived in the Kingdom. 'Una chasa chon due botteghe posta nel popolo di Sancto Stefano al Ponte, la qual chasa tiene a pigione Bartolomeo Carducci, dame l'anno fiorini venticinque. La qual casa è pigionata per l'adietro perché sono istato in Ungharia, ora sono tornato d'Ungharia e voglio tornarvi entro io e abitarvi, però non ò ove abitare altrove [...]'. ASF, Catasto 38. fol. $327 \mathrm{r}$.

39 Archivio Segreto Vaticano, Registri Vaticani 374. fol. 34r. (05/02/1435), 'Arissimo in Christo filio Sigismondo Romanorum Imperatori semper augusto: ac Ungarie et Bohemie regi illustri salutum ictum non possumus non admirari quod cum iam pluries scripserimus ad tuam serenitatem pro liberatione venerabilis fratris nostri Iohannis archiepiscopi Colocensis: qui nulla ex iusta 
from the Count's prison, he managed to regain control over the archbishopric, where he stayed until his death in $1447 .^{40}$

The Da Montebuoni and the Del Bene were in-laws, since one of the Archbishop's brothers, Lorenzo di messer Andrea da Montebuoni, married the daugther of Filippo di Giovanni del Bene. ${ }^{41}$ The two lineages had in fact been connected by marriage since the $1330 \mathrm{~s}^{42}$ The Del Bene, studied by Hidetoshi Hoshino, attributed their ascension into the Florentine elite to their involvement in the domestic wool industry, and, by the early fourteenth century, they had turned into one of the most prestigious actors within that sector. ${ }^{43}$ Their lineage was not extended, though. In 1378, they had five households, located in various parts of the city. ${ }^{44}$ By 1433 , the number of households increased to eight, which were all located in the gonfalons of Vipera and Drago, quarter of San Giovanni, and included 28 family members. ${ }^{45}$ Two of the households did not possess any taxable assets, and the total assets of the households were only 2629 florins, which is surpisingly low given the family enterprises in the wool industry, trade, and politics.

Filippo's father, Giovanni di Amerigo, and his cousin, Jacopo di Francesco del Bene, as members of the political elite, were continously called to the Palazzo della Signoria in order to join the meetings of the secret councils. In the 1370s-1380s, Giovanni, by his active participation as speaker, can be considered to be an influential politician of his time. ${ }^{46}$ In the early 1380 , which they spent in exile, Giovanni and Jacopo built a business network

causa tam diu contra deum et iustitiam carceratus fuit [...].'Archivio Segreto Vaticano, Registri Vaticani 359. fol. 151v.

40 Engel, Magyarország világi archontológiája, I. pp. 66, 515.

41 For the marriage between Lorenzo and Checca and the dowry see: ASF, Diplomatico, Normali, Rinuccini, 13/07/1419; ASF, Monte II. 3733. fol. 165r.

42 Ghetta di Francesco del Bene and Banchello di messer Manente Buondelmonti were married in the 1330s. ASF, Del Bene 27. fol. 8v.

43 Hoshino, L'Arte della Lana in Firenze nel basso medioevo, pp. 153-182.

44 Giovanni d'Amerigo. ASF, Prestanze 367. fol. 4r; Simone di Francesco. Prestanze 367. fol. 9v; Francesco di Tano. Prestanze 367. fol. 1ov; Francesco di Jacopo. Prestanze 368. fol. 4r; Piero Prestanze 368. fol. 21v; Furthermore, the heris of Filippo. Prestanze 369. fol. 28r.

45 Amerigo di messer Albertaccio. ASF, Catasto 455. fol. 3 r; Antonio di messer Ricciardo Catasto 455. fol. 32r; Borgognone di Jacopo. Catasto 455. fol. 55r; Giovanni di Jacopo. Catasto 455. fol. 193r; Vieri di Francesco. Catasto 455. fol. 729r; Agnolo Catasto 498. fol. 35v; Daniello del Gese. Catasto 498. fol. 202r; Nastagio di Niccolò Catasto 495. fol. 36iv.

46 Giovanni d'Amerigo. ASF, CP vols. 11-19. (1370-1381); Jacopo di Francesco. CP vol.2. (1358). 
in Padua and Venice. The family first appeared in the Kingdom of Hungary in 1376 , when the Signoria dispatched Jacopo's son, Bene, juris doctor, as member of a diplomatic contingent, to Louis I's court. While on mission, Bene died in Buda and the commission of his tomb made it necessary for his family to establish the earliest contacts in Hungary. ${ }^{47}$

\section{Filippo di Giovanni del Bene (1372/1374-1427/1431): The Collector of Papal Revenues}

Filippo's entrance into Florentine business life is dated to 1398 , the year of his matriculation into the Wool Guild and that of his marriage with the daughter of Andrea di Tommaso Lamberteschi, who was one of the most influential members of the Guild. Filippo first appears in Hungary less than a decade later, in 1405 , as an agent of Doffo di Nepo Spini's firm. ${ }^{48}$ Doffo, according to his own Ricordanze, was appointed by Alexander $\mathrm{V}$ as a depositary of the Apostolic Chamber and, following that period, John XXIII in the first years of his pontificate maintained the connection with the firm. ${ }^{49}$

Since Filippo's father and Jacopo del Bene were closely related, this might have helped Filippo find his way in Hungary as well as in the Apostolic Chamber. According to Arnold Esch, Jacopo di Francesco del Bene's activity in Rome dates back at least to 1401 , when he was mentioned as local resident. ${ }^{50}$ Two years later, in 1403, we hear for the first time about Filippo staying in Rome..$^{1}$ The functioning of papal collectors in Hungarian territory has been studied in detail by Tamás Fedeles, through an earlier example datable to the 1370 os $^{52}$ Meanwhile, due to the dynastic relations between the Anjou and the Piast and the personal union of the two countries, during Louis I's reign the Kingdoms of Hungary and Poland constituted one collectorial area; starting from Sigismund's time, however, the two were devided into two distinct areas of collectorial activity.

In 1410, Filippo was already serving Pope John XXIII in collection of the tithe. Back then, Filippo was transferring the revenues, collected by the

Prajda, 'Egy firenzei sírköve Budán'.

48 ASF, Signori, Missive, I Cancelleria, 26. fols. 136r-v. (05/12/1405) For Doffo Spini see also: Tripodi, Gli Spini, pp. 22-28, 33-34, 57-62.

49 Holmes, How the Medici, pp. 364-365. For Doffo's Ricordanze see: ASF, CS. II. 13.

$5^{0}$ Esch, 'Florentiner in Rom um 1400', pp. 510-511.

51 Ibid., p. 507.

52 Fedeles, 'Petrus Stephani collector'. 
papal legate, Branda Castiglione, to the Chamber. ${ }^{53}$ His business partner in the enterprise was Matteo Scolari. ${ }^{44}$ On 18 March 1411, the Apostolic Chamber made an agreement with Filippo's uncle, Jacopo del Bene, and Francesco di Giachinotto Boscoli that they would act as joint depositaries. ${ }^{55}$ Basically, all the papal revenues, except for those from Bologna and Forlì, were supposed to pass through their hands. In 1412, Filippo was again heading to Hungary as legate of the Pope with the special mandate to mediate between Sigismund and Venice..$^{6}$ He cooperated closely with his brother, Albertaccio, and kept business relations with a number of other Florentine merchants belonging to the Scolaris' network, among them, Piero d'Andrea Lamberteschi, the Archbishop of Kalocsa, Pagolo di Berto Carnesecchi, and Simone and Tommaso di Lapo Corsi. ${ }^{57}$

While in Hungary, Filippo made acquaintance with Sigismund who, in 1411, accepted him as one of his familiares..$^{8}$ In 1424 , the king conferred upon him the title of Count of the Lateran Palace.59 In the following years, Filippo would have been constantly traveling between Florence, Hungary, and Rome. In 1427, on their way to Hungary, the Florentine ambassadors found him in Segna, in Tommaso di Piero Melanesi's company. ${ }^{60}$ In spite of his several business ties in Hungary, he probably kept his family home in Florence, though there is no indication in his tax return that he did so. $\mathrm{He}$

53 The papal legate, Branda de Castiglione, was supposed to give the collected revenues to Filippo del Bene. Zsigmondkori oklevéltár, II/2. doc. 7839 .

54 Archivio Segreto Vaticano, Registri Vaticani 346. fols. 155r. Published:Zsigmondkorioklevéltár, II/2. doc. 7968. Matteo Scolari included Filippo as one of his creditors in his testament, saying that according to the account books of Niccolò di Angelo Serragli, he owed Filippo 2000 florin for contracts, bulls, and letters of Pope John XXIII. ASF, NA, 5814. fol. 271r. He also appears in the tax declaration of Matteo's heirs. ASF, Catasto 466. fol. $427 \mathrm{~V}$.

55 Holmes, How the Medici, p. 366.

56 Zsigmondkori oklevéltár, III. doc. 2692. In 1413, he is mentioned in the same capacity. Ibid., IV.357. A year later, he was still working as a papal collector in the Kingdom. Zsigmondkori oklevéltár, IV. doc. 1140.

57 In 1452, Albertaccio's sons write in their tax return: 'A Filippo e Lorenzo di Rinieri Scolari per debiti di nostri padri [...]'. ASF, Catasto 703. fol. 147v. See also Jacopo di Filippo's declaration in 1433: ASF, Catasto 455. fol .4r. See the joint declaration of Jacopo di Filippo and his cousins, Amerigo and Baldassare di messer Albertaccio Del Bene. ASF, Catasto 455. fol. 4r There was a business relation between Filippo, Andrea Lamberteschi, and Jacopo di Bartolomeo da Calenzano. See the deposit in the merchant court. ASF, Mercanzia 11780. fol. 3 r. Between Filippo and Piero d'Andrea Lamberteschi. Mercanzia 11780. fol. 40v. See the deposit in the merchant court. Mercanzia 11780 . fol. 4 or.

$5^{8}$ Regesta Imperii, XI. 1. doc. 132. (02/10/1411).

59 Regesta Imperii, XI. 1. doc. 5889. (12/06/1424).

6o See the diary of Luca: ASF, Signori, Dieci di Balia, Otto di Pratica, Legazioni e Commissarie, Missive e Responsive 5. fol. 27v. 
married Lena del Bene dal Barba, whose family operated a money-changing table at the Mercato Vecchio; therefore, the marriage secured him some business connections in Florence.$^{61}$ Filippo's household included his son, Jacopo, born around 1401/1403, his wife, and the sons of Albertaccio. Filippo passed away sometime after 1427 , leaving a very modest family patrimony to his son, which constituted an estate in Petriolo, the parish of San Biagio, and several smaller parcels of land and houses. ${ }^{62}$ By his testament, he commanded his son to construct a family chapel in Petriolo dedicated to San Luca, on which work was still ongoing in $1442 .{ }^{63}$

It is unclear where Jacopo stayed following his father's death. While he covered various offices in Hungary, he also served the Florentine Signoria as an ambassador to King Sigismund. Between 1438 and 1449 he was in Matko Talovac's service as count of the salt chamber in Szeged, and he also held other offices at the salt chambers. ${ }^{64} \mathrm{He}$, like his father, remained throughout his life a resident and citizen in Florence. ${ }^{65}$

In 1442, according to the testimony of his tax declaration, because of earlier business between his father and the Scolari, several lands possesed by Jacopo ended up in Lorenzo di Rinieri Scolari's hands. ${ }^{66}$ In a letter addressed to Pietro de' Medici in 1448, Lorenzo was complaining about the lack of payment on Jacopo's behalf. ${ }^{67}$ The very same letter mentions Lorenzo's return to Florence, which suggests also that he might have been working with Jacopo in the salt mines. The close relations between the two families are also illustrated by the fact that Jacopo del Bene and Lorenzo Scolari became brothers-in-law by marrying the Sapiti sisters, Ladomila and Agnola di Bernardo. It seems to me that they even shared the same house, located in the popolo of San Jacopo Sopr'Arno, which was originally possessed by their father-in-law, Bernardo di Francesco Sapiti. ${ }^{68}$

61 See the declaration in 1433. ASF, Catasto, 474 . fols. $75^{r-76 r . ~}$

62 He reported that he was suffering from gout. 'Filippo del Bene sopradetto d'età d'anni Lv, gottoso e uso di benvivere e con famiglio al servigio suo.' ASF, Catasto 38. fols. 237r.

63 'Facciano adificare una capella di Santo Lucha, posta nella chiesa di Santo Biagio a Petriuolo per testamento di Giovanni d'Amerigho del Bene [...].' ASF, Catasto 667. fol. 268v.

64 Draskóczy, 'Olaszok a középkori Erdélyben', p. 129.

65 ASF, Catasto 812. Numero 64.

66 ASF, Catasto 667. fol. 268v; Catasto 703. fol. 145v.

67 ASF, MAP, filza 16. n. 35 .

68 'Una casa non divisa con l'erede di Domenico Sapiti nel popolo di San Jacopo sopr'Arno [...] ebbi da Bernardo di Francesco Sapiti, mio suocero per parte della dota di Landomina mia donna e figliuola di detto Bernardo.' Jacopo's declaration, submitted in 1452. ASF, Catasto 703. fol. $145^{\mathrm{r}}$. 


\section{The Cavalcanti Family}

The Cavalcanti were also linked to the Da Montebuoni through marriage, as the Archbishop's mother was Giovanni di messer Amerigo Cavalcanti's sister. ${ }^{69}$ Their lineage was similarly of ancient magnate origins; their ancestors lived in the sestiero di San Pier Scheraggio. ${ }^{70}$ They were ineligible for city offices, thus they did not participate at all in politics during the period and we do not find their names among the speakers of the secret councils. Despite their politically unfavourable situation, the Cavalcanti remained one of the most extended lineages of the city. In 1378, they had 35 households located mainly in the gonfalons of Carro, quarter of Santa Croce and Vipera, quarter of Santa Maria. ${ }^{71}$ Among them, messer Amerigo di messer Gianozzo lived in the gonfalon of Vipera..$^{72}$ By 1433 , the number of their households diminished to 25 and included a total of 77 family members. ${ }^{73}$ At that time, Gianozzo di Giovanni, Amerigo's grandson, kept his house in the same gonfalon of Vipera. ${ }^{74}$ The total assets declared by the households amounted to 21,200 florins, but the distribution of the wealth between the households showed great inequality - among them, ten households paid composto.

If Giovanni Cavalcanti ever traveled to Hungary, we do not know. He had already died by the time of the first general census that would allow us to reconstruct his life.

\section{Gianozzo di Giovanni Cavalcanti (b. 1397/1399): The Courtier}

It was Gianozzo, one of Giovanni's sons to appear in the Scolaris' circle. In March 1426, he was among the witnesses of the document, written in Pippo Scolari's Buda house, in which he named the executors of Andrea and Matteo Scolari's testaments.

69 The description of Gianozzo's case makes a short reference to the fact that he and the Bishop were closely related. '[...] Erano a Baccia (Bač, RS) chol'arciveschovo de Buondelmonti che parente stretto di Gianozzo [...]'. ASF, Corp. Rel. Sopp. 78. 321. fol. 98v.

70 Lansing, The Florentine Magnates, Appendix.

71 ASF, Prestanze 367. fols. 9r, 10r-v, 11r-v, 13v, 14r, 28v, 54r. Prestanze 368. fols. 6r-v, 7 r-v, 2or, 44V, 79v. Prestanze 369. fol. 13or.

72 ASF, Prestanze 367 . fol. 11r.

73 ASF, Catasto 488. fol. 33or, Catasto 489. fols. 116v, 287v, 506v. Catasto 491. fols. 22r, 69v, 82r, 104r, 121v, 141r, 226r, 237r, 258r, 265r. Catasto 492. fols. 174v. Catasto 493. fols. 126v, 253v. Catasto 455. fols. 73r, 112r, 417r, 421r, 458r. Catasto 498. fols. 183r, 363r. Catasto 495. fol. 463 r.

74 ASF, Catasto 491. fol. 141r. 
Gianozzo was around a decade younger than his uncle, the Archbishop, and he had not reached legal age by the time of his father's death. ${ }^{75}$ In 1433 , his two brothers, Amerigo and Niccolò, as well as their mother lived in three separate households. ${ }^{7}$ Gianozzo remained with a thirteen-year-old girl, named Brigida, who was probably his wife. The document provides very little information about any kind of business acitivity in which he might have been involved. Similarly, we do not find any firm registered under his name in the 1433 Catasto, despite the business he conducted with his in-laws, Tommaso di Domenico Borghini and Lorenzo di Giovanni de'Medici (1395-1440).

The marriage of Gianozzo's sister Ginevra and Lorenzo brought to the Medici a property located on the ground floor of the Cavalcanti palace, near the Mercato Nuovo. The Medici consequently turned the property into the Medici Tavola. ${ }^{77}$ Similarly, Tommaso Borghini by his marriage with Gianozzo's other sister, Lena, received a warehouse from the Cavalcanti.

By 1427 , the three men had already been running a company together, with branches both in Florence and in Venice. ${ }^{7}$ In March 1425, the firm may have already been operating, when Gianozzo and another Florentine merchant, named Filippo d'Amerigo Frescobaldi, signed a limited liability contract (accomandita) with Tommaso Borghini to take a load of silk textiles to the Hungarian royal court..$^{79}$ They traveled with Matteo Scolari, who at that time was Tommaso's partner in another company set up for textile trade in Hungary. By selling textiles to King Sigismund, the merchants received a good deal of money, though the King remained indebted to them

75 In 1427 , he was 18 years old. ASF, Catasto 68 . fol. 214r. In his catasto declaration, presented in 1433 , his age is not accurate. In the original portate, we read 74 years old, meanwhile the campioni mentions him as 34 years old. Catasto 445 . fol. 297 r. Catasto 491 . fol. 142 r. They presented a correction to their first tax document, in which he is 30 years old. ASF, Catasto 297. fols. 164-167. 76 See their declarations, submitted in 1433. Niccolò di Giovanni Cavalcanti was 23 years old. ASF, Catasto 445. fols. 545r-546r. Amerigo di Giovanni Cavalcanti was 35 years old. Catasto 445 . fols. 7or-71r. Their mother, Costanza. Catasto 445. fols. 322 .

77 The marriage between Lorenzo and Ginevra took place in 1416. De Roover, The Rise of the Medici, p. 19. See also Ginevra's testament, issued in 1444. ASF, MAP filza. 161. fol. 1r.

78 ' [...] Considerati una procura facta in decta corte del decto Giambonino Scolari insino a dì 5 del mese di marzo passato ad petitione di decto Tomaso Borghini procuratore in nome di Gianozo di Giovanni di messer Amerigo Cavalcanti e di Lorenzo di Giovanni de’Medici per se e per suoi compagni e compagnie di Vinegia e di Firenze [...]'. ASF, Mercanzia 7715. fol. 235r. 79 In 1431, Domenico, Tommaso Borghini's son and heir, reported that 'Una mandata di drappi facemmo in Ungheria nell'anno 1424, i quali si dierono in acomanda a Filippo d'Amerigo Frescobaldi e Gianozzo di Giovanni Chavalcanti, e quali venderono alla maestà del re per circha di fiorini 700 o più [...]'. ASF, Catasto 350. fol. 353v. 
for 1300 florins. ${ }^{80}$ On this particular trip to Hungary, Matteo Scolari took with him cash and textiles from Tommaso's warehouse with the value of 900 florins ${ }^{81}$ This put him in debt to Tommaso. The parties had not settled this financial issue with each other by the time of Matteo Scolari's death so it fell to his heirs to deal with the case.

Thanks to the controversial situation, the parties involve - Gianozzo, Tommaso Borghini, and the Scolari nephews - ended up in a quarel in which Gianozzo was forced to rely considerably on his uncle's help. During the history of papacy, popes typically surrounded themselves with and protected their relatives, who lived in their courts either as prelates or as courtiers. ${ }^{82}$ Later examples, depicted in group portraits like the one of Pope Paul III, born Alessandro Farnese (pope from 1534 to 1549), and Pope Leo X, born Giovanni de'Medici (pope from 1513 to 1521), might give us a clear sense of the privileges they enjoyed in their uncle's or cousin's courts. ${ }^{8}$ Gianozzo might have been a similarly protected courtier of his uncle, the Archbishop, who on occasion risked a confrontation with King Sigismund for his nephew.

The roots of the conflict between Gianozzo and the Scolari go back to November 1426, when Pippo Scolari gave a letter to his nephew, Filippo di Rinieri Scolari, which testified that the Count of Segna and Modrus was indebted to him. ${ }^{84}$ However, Pippo himself owed 1000 florins to the Medici of Venice. ${ }^{85}$ Pippo died in December, so the duty to recover the money from the Count fell to Filippo di Rinieri Scolari. The King seemingly

8o The document describing the case might be a short memo, prepared by/for Filippo Scolari: 'Al nome sia di Dio amen. In su questo foglio faremo richordo apunto chome la chosa di Gianozzo Chavalchanti e Filippo Freschobaldi è passata di danari di Filippo Scholari che si voleano chonvertire a lloro essere.' ASF, Corp. Rel. Sopp. 78. 321. fol. 98r. In 1429, Filippo reported the King's debt of 1300 Florentine florins in their tax return. ASF, Catasto 297. fols. 31v.

81 Matteo Scolari took textiles from Tommaso's silk workshop and warehouse in the value of 730 Florentine florins. For the court case, see: ASF, Mercanzia 7114bis. fols. 63r-v, 134v-136r.

82 The term cortigiano ('courtier') appears already in contemporary documents. For example, in 1427, maestro Giovanni del maestro Antonio da San Miniato mentions in his tax document that a certain 'messer Giovanni Azel tedescho, cortigiano abitava qui quando c'era il papa [...]'. ASF, Catasto 79. fol. $48 \mathrm{v}$.

83 Tiziano, Pope Paul III and his Grandsons, Museo di Capodimonte, Naples, 1546; Raffaello, Portrait of Leo X with two Cardinals, Uffizi Gallery, 1518-19. For the study of the phenomenon see: Court and Politics in Papal Rome.

84 In 1429, Filippo Scolari reported that he had '[...] Ancora pretende avere ragioni contra a Gianozzo Cavalcanti [...]'. ASF, Catasto 296. fol.16or.

85 See the contemporary copies of letters collected for the case: 'Copia di più lettera da Buda, le quali parlano sopra i danari 1000 s' ànno avere dal Conte di Signa per parte di messer Filippo Spano.' ASF, Corp. Rel. Sopp. 78. 326. fols. 37or-v. 
wished to help Filippo in the beginning, but the Count refused to pay. ${ }^{86} \mathrm{~A}$ couple of months later, both the ruler and Filippo Scolari, accused Gianozzo Cavalcanti of business misconduct, instead of demanding payment from the Count. The Scolari originally wished to eliminate their debt by giving the Count's money to the Medici. Both the Count's and Gianozzo's claims in the matter likely stood in sharp contrast to each other, which then made Filippo Scolari suspicious. Whether these accusations were true or false, and whether the Count had finally paid his debt to Gianozzo, we do not learn explicitly from these sources.

The act of standing against the Count of Modrus, one of the most important barons in the royal court, surely exceeded the limits of an ordinary Florentine merchant in Hungary. In the meantime, Filippo Scolari brought the case in front of the Merchant Court by claiming that Gianozzo and Filippo Frescobaldi wanted to turn the money to their own interests. ${ }^{87} \mathrm{At}$ that point, Gianozzo's situation, both in Florence and in Hungary, was worrisome, and the help of his uncle the Archbishop became crucial. When the case started to escalate, he found shelter in Kalocsa to hide from the King's anger. ${ }^{88}$ Sigismund had even demanded the money from the Archbishop, which Gianozzo had supposedly taken from the Count of Modrus. ${ }^{89}$

The Archbishop's help, though, did not prove to be sufficient, and in 1427 Gianozzo ended up in Sigismund's prison. Whether Gianozzo's

86 The letter was written on 28 June 1427. Two other letters were sent, one on 19 August 1427, and 16 January 1428. ASF, Corp. Rel. Sopp. 78. 326 . fol. 370v. See Sigismund's decision, verbalized by the royal chancellery. ASF, Corp. Rel. Sopp. 78.326 . fols. 262 r-v.

87 ' [...] In su questo foglio faremo richordo apunto chome la chosa di Gianozzo Chavalchanti e Filippo Freschobaldi è passata de danari di Filippo Scholari che si voleano chonvertire a lloro essere.' ASF, Corp. Rel. Sopp. 78. 321. fol. 98r.

88 'Copia d'una letta che l'omperadore scrisse al'arcivescovo di Coloccia che sostenesse Gianozzo [...]'. ASF, 78. 326. fols. 262v-263r.

89 'Item uno effetto publico scritto per mano di publico notaio per la quale apparisse come il serenissimo principe et signore Sigismondo imperatore de romani scrisse lettera al arcivescovo di Collocia che in quanto Gianozzo Cavalcanti predecto non vole esser dare e pagare i certi assegnamenti che esso imperatore aveva facti per denari 2000 che il decto Gianozzo aveva ricevuti dal Conte di Segna in nome di messer Pippo Scolari e per suoi facti che esso ritenesse questo, il decto Gianozzo decta partita. Et come il decto arcivescovo di Colloccia avendo auti resposta dal decto Gianozzo che la decta partita aveva distribuita e derogati come doveva lo fece pigliare e detenere e messe decto Gianozzo nel carcere.' ASF, Mercanzia 7115. fol. 98r. Furthermore, see the copy of a letter written by Sigismund's chancellery to Giovanni Buondelmonti in Gianozzo's case: '[...] I decti danari precisamente tocchano alla nostra Maiestà [...]'. ASF, Corp. Rel. Sopp. 78. 326. fol. 262v. Furthermore, see a document issued by a public notary in Florence: Corp. Rel. Sopp. 78. 314. fols. 18-19. See other documents regarding the case at the Merchant Court: ASF, Mercanzia 7118 . fols. $46 \mathrm{v}-47 \mathrm{r}$. 
imprisonment resulted from a court procedure in Hungary, or if he was taken only by the King's order, is not to be found in the documents. However, more than a year later, in March 1429, the Latin consul, Leonardo di Nofri Bardi, as relator of the case in the royal court, received a letter from the Signoria asking for a favourable outcome for Gianozzo. ${ }^{90}$ But this was long after Gianozzo's capture and might have been only a formality, which did not mean that there was anyone truly investigating the case in Hungary.

The Archbishop and the Medici likely mobilized Florentine diplomacy in favour of their relative and in-law. In April 1428, Piero di messer Luigi Guicciardini, who arrived during the summer of 1427 as an ambassador in Buda, was completing a mission on behalf of the Merchant Court with the intent of obtaining Gianozzo's deliberation. ${ }^{91}$ In 1428, the three business partners, Gianozzo, Tommaso Borghini, and Lorenzo di Giovanni de'Medici, even asked for another Scolari nephew, Giambonino, to be captured at the Merchant Court for the debt. $9^{2}$ Gianozzo was finally released that year, thanks to the intervention of the Florentine as well as the Milanese ambassadors.

However, the court processes moved slowly, and Giambonino Scolari, in a letter written on 27 May 1429, and addressed to his brother Filippo noted with preoccupation that Gianozzo's case at the Merchant Court was not yet concluded and that the Calimala Guild was about to call together a meeting on the issue. ${ }^{93}$ On 4 March 1430, when submitting his tax return, Filippo Scolari claimed that the litigation had not yet concluded. ${ }^{94}$ Interestingly, all these serious issues of imprisonment and requests for capture did not completely destroy the business ties between the Scolari and the Borghini. Tommaso Borghini's son Domenico still worked in close cooperation with the Scolari nephews in Venice while the case was ongoing.

90 ASF, Signori, Missive, I. Cancelleria 32. fols. 52v-53r.

91 'Io sia dinanzi alla reale Maestà a suplicare la liberatione di Giannozo di Giovanni Cavalcanti.' ASF, Corp. Rel. Sopp. 78. 326. fol. 337r.

92 ASF, Diplomatico, Normali, Rinuccini 12/04/1428.

93 'Vero che per anchora del fatto di Gianozo non è concluso e che ala Merchadantia [...] me scrivi che l'Arte di Chalimala si doveva ragunare e farne conclusione che è cossa che molto mi piase pure sia presto [...]'. ASF, Corp. Rel. Sopp. 78. 326. fol. 354r.

94 ASF, Catasto 296. fol. 16or. 


\section{$4 \quad$ The Borghini Family}

The Borghini became the Cavalcantis' in-laws by the marriage between Gianozzo's sister Lena and Tommaso di Domenico Borghini. The Borghini, who acquired a name for themselves over the course of the fourteenth century, were of popolani origins. ${ }^{95}$ In 1378 , they had only one household registered in the tax document under the name of Zanobi di Taddeo, who lived with his family in the gonfalon of Bue, quarter of Santa Croce.$^{96}$ Both Zanobi and his brother, Domenico di Taddeo, were active participants of the secret councils. ${ }^{97}$ In 1433, only Tommaso's son, Domenico, submitted a tax return for the family. His household was composed of seven family members and was located in the gonfalon of Bue, quarter of Santa Croce..$^{8}$ He declared 2883 florins of total assets and paid two florins and eighteen soldi of catasto. The Borghini, thus, was a completely new family in the Florentine social scene, but its members already occupied a place in the political elite. There is no evidence that they had any connections in the Kingdom of Hungary prior to Pippo's presence in the royal court.

Despite their new social status in Florence, the family's participation in silk manufacturing and long-distance trade went back at least to the $1390 \mathrm{os}$. By 1395, Tommaso's distant uncle, Tommaso di Orlando Borghini, appears as Francesco di Marco Datini's agent in Avignon. ${ }^{99}$ In 1402, we find him back in Florence, where he seemingly started to produce silk textiles with his new firm, which he had set up with Lorenzo di Dinozzo. ${ }^{100}$ Tommaso, indeed, might have belonged to the first generation of those silk manufacturers of Florentine origins who invested financial and human capital into silk companies. At that point, Florentine silk production could hardly have been called foreign-oriented; the production was probably limited to fulfilling

95 According to my studies, the first reference of the family is dated to $135^{\circ}$, when a notary act mentions a certain Tommaso Borghini. ASF, NA, 14004. fol. 26v.

96 The other households seem to be unrelated to this one, even though the Tratte, that is, the list of office holders, mentions more persons with the Borghini family name, like Zanobi di Taddeo Borghini. ASF, Prestanze 367. fol. 24r.

97 Zanobi Borghini: ASF, CP 24. fols. 10v, 13r, 34v, 39v; CP 28. fols. 47r. Domenico Borghini: CP 14, fol. 52v; CP 23. fols. 2v, 10v, 12r, 16v, 18r, 20v, 29r, 30v, 33r, 139v, 143r, 145r, 146r, 148v.

98 ASF, Catasto 491bis. fol. 15ov. In 1427, the household included Domenico (aged 56), Lena, his wife (aged 32), his offspring Domenico (aged 17), Giovanni (aged 14), Mattea (aged 8), Checca (aged 4), and Marietta (aged 3). ASF, Catasto 29. fol. 667.

99 See the correspondence with Datini. AD, busta 429, inserto 26, codice 507126; busta 430, inserto 18 , codice 50712. His brother Cristofano di Orlando at that time was staying in Arles. $\mathrm{AD}$, busta 620 , inserto 17 , codice 508660 .

$100 \mathrm{AD}$, busta 501, inserto 20, codice 503660 . 
the needs of the domestic market. Only the supply of raw silk required the involvement of international merchants, because it originated in distant locations.

\section{Tommaso di Domenico Borghini (c. 1381-c. 1428/1430): The Pioneer Silk Enterpreneur}

The domestic silk industry, as Sergio Tognetti claims, underwent its initial phase of development in the first part of the fourteenth century, when skilled workers from nearby Lucca arrived in the city. ${ }^{101}$ Lucca, as the earliest centre of silk manufacturing in Italy, dominated the market for the entire fourteenth century. Following Venice, Florence stood as the third largest silk manufacturing centre in the Italian Peninsula. ${ }^{102}$ As a consequence, silk textile turned into the first product manufactured in Florence, which Florentine merchants sold throughout western Europe. ${ }^{103}$ It took probably forty years for the second generation of silk manufacturers and entrepreneurs to appear on the scene and they seem to have been descendants of the first investors. By that time, the sector had already started to employ Florentine merchant networks abroad for the distribution of their finished silk fabrics. Tommaso, therefore, belonged to this second generation of businessmen who was engaged both in the production and in the marketing of silk textiles abroad. His success in the silk sector may be attributed to his uncle and brother, who might have helped him in investing human and financial capital into his enterprise.

Tommaso's elder brother Jacopo was a wool manufacturer who, with his partner, Zanobi di Cambio Orlandi, ran a workshop in the convent of San Martino. ${ }^{104}$ In 1401, Jacopo died and Tommaso was to inherit the business and probably the profit obtained by his brother. In December 1405, the firm owned by Tommaso's uncle and Lorenzo di Dinozzo still existed. ${ }^{105}$ The know-how in silk manufacturing came from his uncle who, by his death,

101 Tognetti, 'La diaspora dei lucchesi'.

102 Molà, The Silk Industry of Renaissance Venice.

103 Goldthwaite, The Economy of Renaissance Florence, pp. 282-295.

104 '[...] D'una compagnia chel detto Zanobi di Cambio Orlandi el detto Jacopo di Domenicho Borghini ebbono insieme già e più tempo in fare e in far fare una bottegha d'Arte di Lana nel Convento di San Martino della città di Firenze la quale compagnia e bottegha duro per spatio e termine di tre anni e mezo la quale compagnia e bottegha si partiva in tre parti cioè chel detto Zanobi di Cambio Orlandi ne tocchava parti due e al detto Jacopo di Domenicho Borghini ne tocchava parte una [...]'. ASF, Arte della Lana 325 . fol. 39v.

105 AD, busta 870 , inserto 11, codice 901229 . 
left business obligations and contacts for his nephew. ${ }^{106}$ This suggests that Tommaso's silk firm was probably the continuation of his uncle's business. ${ }^{107}$ The location of his silk workshop is uncertain, although Tommaso received a workshop-warehouse from the Cavalcanti as part of his wife's dowry; it was situated in the Via Nuova dei Cavalcanti, in the parish of San Romolo. However, in 1427, it was reported to be used by the Cavalcanti themselves. ${ }^{108}$ Tommaso might have started the activity on his own sometime around 1410, the year when his enrollment as a silk manufacturer was registered at the Por Santa Maria Guild. In the following years, he grew into one of the most respected members of the guild and was elected to consul nine times. ${ }^{109}$

Tommaso's pioneering activity in the silk manufacturing business cannot be separated from an important innovation in the sector that helped build the reputation for Florentine fabrics. In 1420, the introduction of this technical novelty was commemorated in the statutes of the Por Santa Maria Guild, which state that Tommaso, in cooperation with two other businessmen, sponsored the earliest production of metallic threads for the silk sector in Florence. ${ }^{110}$ One of his fellow manufacturers mentioned in the document is Tommaso's partner, Giorgio di Niccolò di Dante Ughi, with whom he established a company for the manufacturing of gold and silver threads in $1423 .{ }^{111}$

106 Following their father's death, Tommaso's son declared that they still had outstanding credit, which was left by the company owned by Tommaso Borghini and Lorenzo di Dinozzo. See his sons' declaration, in 1431: 'E più dobbiamo avere dalla compagnia che fu di Lorenzo di Dinozzo e Thommaso Borghini e compagni circha di fiorini xxv, i quali denari faciamo perduti.' ASF, Catasto 350. fol. 353v.

107 AD, busta 870, inserto 11, codice 901229.

108 In 1427, it was reported to be used by members of the Cavalcanti family as a tailors' workshop. See Tommaso's tax declaration, in 1427: 'Una bottegha, overo fondacho posto nel popolo di Santo Romolo, nella Via Nova de Chavalchanti, da primo via, da secondo è chapitani della Parte Ghuelfa, a terzo e a quarto detti chapitani. La quale bottegha, overo fondacho abiamo e tegniamo per dotta di monna Lena, donna del detto Tomaso, per fiorini dugiento, carta fatta per mano di ser Ghuido di messer Tomaso, notaio fiorentino [...]'. ASF, Catasto 29. fol. 664r.

109 ASF, Arte di Por Santa Maria 246. fol. 8r, (1410), Arte di Por Santa Maria 246. fol. 8v (1411), Arte di Por Santa Maria 246. fol. 9v (1415), Arte di Por Santa Maria 246. fol. 10v (1417), Arte di Por Santa Maria 246. fol. 11r (1419), Arte di Por Santa Maria 246. fol. 12r (1421), Arte di Por Santa Maria 246. fol. 13r (1423), Arte di Por Santa Maria 246. fol. 14r (1426), Arte di Por Santa Maria 246. fol. 15 r. (1428).

110 '[...] Nel 1420 s'inchominciò in Firenze a far filare l'oro et battere foglia da filare oro e fu l'arte di Por Santa Maria, cioè tra mercanti d'essa a loro spese e sotto nome dell'arte, che fu Tommaso Borghini, Giorgio di Niccolò di Dante e Giuliano di Francesco di ser Gino (Ginori). Costò gran denaro a conducerci è maestri e maestre.' Dini, Manifattura e commercio, p. 47.

111 For one of the firm's account books, see: 'Giorgio di Niccolò di Dante Ughi e Tommaso di Domenico Borghini e chompagni del'oro e del'ariento filatto [...]'. ASF, Ughi 67. fols. 1v-21v. See 
Marketing of the firm's products abroad followed a pattern different from that of the major wool companies, which relied on Florentine merchant networks for distribution. Tommaso, in fact, decided to found a merchant company with Matteo Scolari for selling his own silk in the Kingdom of Hungary. ${ }^{112}$ This pattern seems to be typical of other Florentine silk companies as well, like that of the Corsi and Melanesi brothers, who intended to enter their products into the Hungarian market. The production of Tommaso's firm might have been rather voluminous; Matteo Scolari, by his death, remained indebted to them for 900 Florentine florins. Because of liquidity problems experienced by Matteo's heirs, Tommaso was entitled to retain the income and later on the property rights of Matteo's estates, located in the parish of Santo Stefano a Campi. ${ }^{113}$

As the third generation of silk manufacturers, Tommaso's sons started their careers in the industry on their father's side. ${ }^{114}$ In 1428, he and his sons, Domenico (b. c. 1411) and Giovanni (b. c. 1413) started a new silk workshop and gave a minor share to Jacopo di Bonifazio Russi. Tommaso died sometime following the founding of the company, and his heirs, maybe after a couple of months or one or two years, decided to discontinue the activity. In January 1431, we find in their declarations that the capital belonging to Tommaso's

also Giorgio's tax return, presented in 1427: ASF, Catasto fols. 970-973v.

112 See the case of Matteo's debt at the Merchant Court. ASF, Mercanzia 7114bis. fols. 63r-v, 134V-135r. The company kept in contact with other Florentine merchants working in Hungary who belonged to the Scolaris' business network, like Simone di messer Andrea da Montebuoni and Filippo Frescobaldi. 'Qui apreso faremo richordo di tutti debitori e creditori che si trova nella bottegha di Tomaso Borghini proprio, cioè nell'Arte della Seta, debitori a libro biancho segnato J. messer Matteo Scholari tra i danari adietro e spese fatte per una sentenzia abiamo chontro ale rede e beni di detto messer e chosti ch' à tenuto Giovanni de Medici a chanbi in tuto fiorini 911 [...] Simone di messer Andrea da Montebuoni carta 4, fiorini 64. Filippo Freschobaldi debitore chativo però che quello che in Ungheria per noi e da gli avere da rre d'Ungheria e no' ne faciamo chonto niuno [...]'. ASF, Catasto 29. fols. 665v-666r. See his sons' tax declaration, submitted in 1431: Catasto 350. fol. 353v.

113 See the declaration of the heirs from 1427: 'Uno podere posto nel popolo di Santo Stefano a Chanpi, lugho detto Al fornello, con casa da signore e da lavoratore [...] Uno podere posto in detto popolo, lugho detto Il fornello [...] Uno podere posto in detto popolo, luogho detto Gricignano [...] I sopradetti 3 poderi à presi Tomaso Borghini e conpagni per fiorini goo àno avere e degliene àno la rendità [...]'. ASF, Catasto 59. fol. 871v. ‘Tommaso Borghini e conpagni setaiuoli deono avere fiorini 900 che tengono 3 poderi a Canpi come n'abiamo fatto conto a pie de poderi [...]'. ASF, Catasto 59. fol. 875r.

114 See the surviving index of the matriculations mentioned in both Domenico's and Giovanni's names; however, the years of their admittance to the guild remain unclear. Meanwhile, Tommaso's third son, Piero, was enrolled in 1425. ASF, Arte di Por Santa Maria 28. fol. 1v. 
heirs was 1718 florins, while Russi's part was 1194 florins. ${ }^{115}$ The decision taken by the Borghini brothers might have had a lot to do with the fact that Domenico had been working in Venice as an international merchant as early as 1427. Earlier, his father, Gianozzo di Giovanni Cavalcanti, and Lorenzo di Giovanni de'Medici had operated a firm in Venice. In March 1427, Domenico became a partner of Agnolo di Zanobi Gaddi (c. 1398-) in a merchant company that traded with precious metals and stones, where Agnolo's share was 3500 Venetian ducates. ${ }^{116}$ The Gaddi had already developed good connections in Venice, as they had moved to the city sometime before 1390 and grew into an important family of the local Florentine community. ${ }^{117}$ In 1431, in the company balances, Agnolo declared that their firm retained three-eighths of two lands in Santo Stefano a Tizzano, in the neighbourhood of Matteo Scolari's former property, as a business debt. This seems to confirm that the Gaddi and Borghini of Venice earlier had kept strong business ties with Matteo Scolari and that maybe the lands were meant to clear an outstanding debt. ${ }^{118}$ Domenico di Tommaso Borghini's surviving letters addressed to Giambonino and Filippo di Rinieri Scolari also strengthen the hypothesis that the strong business ties between the two families, even after 1426, remained uninterrupted. ${ }^{119}$

115 See his sons' declaration from 1431: 'E più ci troviamo in sulla bottegha dell'Arte della Seta in compagnia di Jacopo di Bonifazio Russi, la quale compagnia cominciò a dì xxv d'ottobre $1428 \mathrm{e} \mathrm{di}$ poi non se saldo alcuna ragione. Ma in detta compagnia mettemmo di corpo tra denari contanti e debitori e mercatantie fiorini 1718 d. vii a ffiorini. Così siamo creditori al libro secreto.' ASF, Catasto 350. fol. 353r. 'A voi sigori uficiali del chatasto qui apresso faremo richordo noi rede di Tommaso Borghini e Jachopo di Bonifazio Russi di quello ci ritroviamo questo dì 31 di gienaio 1430 di chorpo in sulla botegha dell'Arte della Seta ciaschuno per la parte sua, chome apresso diremo chontando debitori e creditori e merchatantie abbiamo in detta compagnia. Rede di Tomaso Borghini ànno di chorpo in detta compagnia chome apartitamente a libro secreto segnato B. da 3 a 5 fiorini mille setteciento diciotto s. d.7. a ffiorini. fi. 1718. s. 2. aff. Jachopo di Bonifazio Russi à di chorpo in detta compagnia chome apare partitamente a libro segreto segnato B. da 5 a 6. fiorini mille ciento novantaquatro s. xxiii d. 6 a ffiorini. fi. 1194 s. 23. d. 6. Troviamo in detta compagnia drappi di seta di più ragioni fatti in botegha per fiorini mille seicento venti s. 22. d. 11 a ffiorini [...]'. Catasto 350 . fol. $356 \mathrm{r}$.

116 See the fragments of the account book of the company of Lorenzo Tacchini and Raimondo Manelli of Avignon: '1430 chopia d'uno conto àuto da Vinegia da Agnolo Ghaddi e Domenicho di Tommaso e compagni [...]'. ASF, CS, serie V. 176o. fol. 102r. In 1431, in his tax declaration, Agnolo mentioned that he founded the company with Tommaso on 26 March 1427. ASF, Catasto 380. fol. 39v. ASF, CS serie V. 1760. See Agnolo di Zanobi Gaddi's declaration in 1431. ASF, Catasto 380. fol. $39 \mathrm{v}$.

117 For the Gaddi in Venice see: Mueller, Money and Banking, pp. 268-270.

118 ASF, Catasto 380 . fol. $41 \mathrm{v}$.

119 Domenico was probably an apprentice of the Medici of Venice and, as business partners, sent frequent letters to the Scolari brothers. For his letters see: ASF, Corp. Rel. Sopp. 78. 326. fol. 
The Da Montebuoni also established social ties to one of the most important families of the Medici faction, the Guicciardini, with the Archbishop's sister Agnola di messer Andrea da Montebuoni marrying Piero di messer Luigi Guicciardini. ${ }^{120}$ The Guicciardini were documented in Florentine sources as early as the mid-twelfth century, and following the Black Death they became one of the most prominent popolani lineages. ${ }^{121}$ Despite their social status, the number of their households remained modest during the entire period. In 1378 , the officers of the estimo recorded eight households in the city, all of them located in the gonfalon of Nicchio, quarter of Santo Spirito. ${ }^{122}$ By 1433, the number of households had not changed and only one household was located elsewhere. ${ }^{123}$ They declared 29 family members and 33,865 florins of total assets. One of the households paid only composto and the catasto of the other seven amounted to 46 florins, 59 soldi, and 33 denari.

The Guicciardini were heavily involved in politics throughout the fourteenth century, and we encounter their names often in the registers of the secret councils. Piero's father, messer Luigi di Piero (†1403), an active politician himself, was dispatched abroad several times by the Signoria as head of the diplomatic contingents. He also participated as speaker in the meetings of the secret councils on a regular basis. ${ }^{124}$ At the time of his death, he was mentioned as one of the richest men in Florence. The family had

340r-v. (30/04/1429); fol. 341r-v. (07/05/1429); fol. 344r-v. (14/05/1429); fol. 346r-v. (21/05/1429); fol. 357r-v. (28/05/1429); fol. 387r-v. (04/6/1429); fol. 359r-v. (11/06/1429); fol. $365^{r-v . ~(23 / o 6 / 1429) . ~}$ 120 She was his third wife, before he had a Valori and an Acciaiuoli. Goldthwaite, Private Wealth, p. 108. The date of his third marriage is uncertain, but given the fact that Agnola da Montebuoni was 36 years old in 1427 , we can only suspect that, according to Florentine customs, she was still in her teens when she married Piero. See Piero's declaration: ASF, Catasto 65. fol. 54r. (1427); Catasto 335. fol. 577r. (1431)

121 For the history of the lineage and their genealogical tree, see: Goldthwaite, Private Wealth, pp. 108-155. Brucker, Florentine politics and society, pp. 124-125.

122 Federigo di Leone. ASF, Estimo 268. fol. 35r; Margherita di Angelo di Puccio. Estimo 268. fol. 45r; Luigi di messer Piero. Estimo 268. fol. 64v; Dardano di Niccolò. Estimo 268. fol. 66r; Jacobo di Luca. Estimo 268. fol. 68r; Leoncino di Niccolò. Estimo 268. fol. 68r; Francesco di Niccolò. Estimo 268. fol. 68r; Sandro di Niccolò. Estimo 268. fol. 79v.

123 Agnoletta di Simone di Jacopo di Luca. ASF, Catasto 499. fol. 73v; Battista di Niccolò di messer Luigi. Catasto 488. fol. 53r; Giovanni di Niccolò di messer Luigi. Catasto 488. fol. 162v; Giovanni di Francesco. Catasto 488. fol. 187v; Ghino di Lioncino. Catasto 488. fol. 19or; messer Giovanni di messer Luigi. Catasto 488. fol. 20ov; Piero di messer Luigi. Catasto 488. fol. 318v; Pagolo di Francesco. Catasto 488. fol. 340v.

124 There are 68 speeches registered under his name. ASF, CP vols. 20-36. For the offices held by him, see: Goldthwaite, Private Wealth, pp. 111-112. 
seemingly no connection to Hungary before Pippo's time, and the relation between the two families might have been based entirely on the in-law ties which linked them to the Da Montebuoni.

\section{Piero di messer Luigi Guicciardini (1378-1441): The Ambassador}

Piero did not have much interest in business, but, rather, in politics. It is not surprising, therefore, that the entire 1433 catasto does not mention a single firm registered under his name. ${ }^{125}$ During his political career, he became an important supporter of the Medici. ${ }^{126}$ Like his father, Piero was an active member of the secret councils and in the period between 1413 and 1433, he was registered 54 times as a speaker. ${ }^{127}$ Besides domestic politics, diplomacy was his major field of expertise. In the 1420 s and 1430s, he led numerous diplomatic missions to foreign courts, among them to King Sigismund, the King of Aragon, the Pope, Milan, and Venice.

His earliest connections to Sigismund's court remain somewhat unclear. According to the chronicle of Bartolomeo di Michele del Corazza, Piero threw a party in 1410 on the occasion of Pippo Scolari's visit in Florence that involved dining, hunting, and jousting. ${ }^{28}$ Six years later, Sigismund had probably conferred a noble title on him. ${ }^{129}$ Beyond these details, one document issued in Pippo's Buda house, naming him as one of the executors of Matteo and Andrea Scolari's testaments, informs us that Piero was acquainted with the Scolari. In 1427, his pre-existing relations to the Da Montebuoni and the Scolari might have also led to his appointment as an ambassador of the Florentine Signoria to Sigismund. As Isabella Lazzarini pointed out, during the fifteenth century, a 'mixture of family and personal elements played a crucial role in being chosen as an ambassador.'130 She has

125 Excluding the list of debtors and creditors. His tax declaration mentions only the fact that his son invested in a firm he ran with messer Giovanni Gucciardini. ASF, Catasto 434. fol. 337v. 126 Goldthwaite, Private Wealth, pp. 113-115. No Gucciardini account books survived from the period; therefore, Goldthwaite determined the wealth of the family exclusively on the basis of their catasti.

127 ASF, CP vols. 41-49. His name was registered until 1437 among the speakers at the secret councils.

128 'E alcuno cittadino fece a lui convito; fra' quali furono molti giovani cittadini che gli feciono un desinare al luogo di Piero di messer Luigi Guicciardini, al ponte a Grieve: e feciono un bello e ricco convito e una caccia nel giardino di detto Piero. E poi, dopo il mangiare, feciono in sulla Grieve una bella giostra: furono da sei o otto giovani. Andovvi di Firenze più di III mila cristiani. Fu delle belle feste ch'io vedessi mai, di simile cose.' Del Corazza, Diario fiorentino, p. 26.

129 Goldthwaite, Private Wealth, p.117.

130 Lazzarini, Communication and Conflict, p. 125. 
shown that Bonaccorso di Neri Pitti's (1354-1432) success as an ambassador rested on the personal network that he built in the French royal court, when he was sent on multiple occasions to the Kingdom of France. ${ }^{131}$ Piero's case, therefore, was definitely not a unique one. Earlier, in 1426, Rinaldo di messer Maso degli Albizzi was dispatched by the Florentine government to Hungary; he was then a soon-to-be in-law of the Scolari. In Florentine diplomacy, the private side of ambassadorial appointments might have tried to ensure the success of diplomatic missions by considering the social network available for helping ambassadors perform their task. Consequently, embassies might have been designed to serve both diplomatic and private interests.

The crucial role of temporary embassies rested on the peaceful resolution of diplomatic conflicts with foreign powers, since a military confrontation might have disturbed Florentines' trade in the given region. The strong intersection between trade and diplomatic interests of members of the Florentine political elite resulted in the selection of a high number of international merchants to fulfill ambassadorial tasks. ${ }^{132}$ The diplomatic missions that led to the Kingdom of Hungary confirmed in several ways Brian J. Maxson's claim that around the turn of the fourteenth and fifteenth centuries, Florentine diplomatic practices already pointed toward the careful selection of potential ambassadors. ${ }^{133}$ Even though ambassadors were appointed by the Signoria itself, members of the political elite in the framework of the secret councils had the ability to advocate for possible candidates. The ratio between the suggested and the accepted personnel for a given diplomatic contingent must have been very high.

In early Renaissance Florence, embassies typically included three persons at the head of the contingent: a politician who was likely also an important international merchant, an educated man, and a notary or so-called chancellor of the embassy. The politician's expertise typically included trade in

131 Lazzarini, 'Mercatura e diplomazia', pp. 277-283.

132 Lazzarini, 'Mercatura e diplomazia'. Ibid.,' I circuiti mercantili della diplomazia italiana nel Quattrocento'. Prajda, 'Trade and Diplomacy in pre-Medici Florence'.

133 It can be considered the most active period of the Florentine diplomacy in relation to the Hungarian ruler, with four embassies following each other in the years 1424, 1426, 1427, and 1428 . In all these cases, the Signoria assigned its most influential politicians to the court. Among them were Biagio di Jacopo Guasconi (1424), Rinaldo di Maso degli Albizzi (1426), and Piero di messer Luigi Guicciardini $(1427 ; 1428)$. Besides them, also learned men, like Bene di Jacopo del Bene (1376), juris doctor, Nello di Giuliano Martini da San Gimignano (1426), similarly juris doctor, and Luca di Maso degli Albizzi (1427) traveled with the embassies. As Maxson has observed, educated men with good rhetorical skills were more likely to be appointed as ambassadors. Maxson, The Humanist World of Renaissance Florence, Chapter 6. 
addition to politics, while orations and diplomatic communication were left for the second, learned man. The skills and selections of this position, described by Brian Maxson, show that the differences between the two ambassadors were significant, and these two distinct tasks required two or three persons. The Signoria, in all the cases known to us, assigned its most influential politicians to the Hungarian court. Among them were Biagio di Jacopo Guasconi (1424), Rinaldo di Maso degli Albizzi (1426), and Piero di messer Luigi Guicciardini (1427).

Among the individuals studied in the present volume, businessmen like Andrea di messer Lorenzo Da Montebuoni, Rinaldo di messer Maso degli Albizzi, and Vieri di Vieri Guadagni often performed in diplomatic capacities. ${ }^{134}$ In fact, international merchants' participation in ambassadorships might have considerably facilitated the Signoria's attempt to maintain trade and political connections with the Kingdom of Hungary. These businessmen also used their sojourn for networking purposes with their fellow Florentines and Hungarian dignitaries. ${ }^{135}$ The practice of cultivating business ties during diplomatic missions is best illustrated by the travel accounts of the Albizzi brothers, Luca and Rinaldo di Maso. Sources produced during their trips to Hungary suggest that networks of Florentine merchants abroad might have contributed considerably to the success of diplomatic missions, and that Florentine ambassadors very often relied on the help of their fellow citizens abroad. Diplomatic journeys might have been organized both financially and logistically like commercial trips: they used the same trading routes and ambassadors similar to merchants, and they seem to have recorded the daily expenses of their trip, important information for the Signoria. Rinaldo and Luca met several Florentine merchants during their trips; Luca mentioned that in Venice two of them, Tommaso Melanesi and Filippo di Giovanni del Bene, were heading to Hungary by sea. Another merchant, Tommaso Schiattesi, even joined him on his way to Segna (Senj, SLO). ${ }^{136}$

134 See as examples: ASF, CP vols. 43, 44. Obtained business interests in the papal court in Rome, where Vieri was sent several times by the Florentine government

135 The persona of Simone Peruzzi's fellow ambassador and the circumstances of his assignment provide another case for the intersections between diplomatic missions and establishing Florentine commercial ties abroad. Prajda: Diplomacy and trade. Guicciardini sent a letter to Simone and Tommaso Melanesi on 3/11/1427, from Barcs, informing them that Luca was going back to Florence and that Jacopo Riccardini, the chancellor of the mission, had arrived in Hungary. ASF, Signori, Dieci di Balia, Otto di Pratica, Legazioni e Commissarie, Missive e Responsive 7. fol. $7 \mathrm{r}$.

136 Prajda, 'Egy firenzei követjárás'. 
In addition, learned men, such as the jurist Bene di Jacopo del Bene (1376), Nello di Giuliano Martini da San Gimignano (1426), and Luca di Maso degli Albizzi (1427), traveled with the embassies to Hungary. Piero Guicciardini, in this sense, did not belong to any of these groups; he was neither a learned man nor a merchant himself. He belonged to those very few men who retained politics as their primary focus.

As compared to other examples of Florentine diplomatic contingents in Hungary, the embassy led by Piero in 1427 provides us with an eloquent example of ambassadorial practices in pre-Medici Florence. The most important sources in this regard are Piero's fellow ambassador's travel accounts, particularly Luca di messer Maso degli Albizzi's, who recorded several important details of his appointments and journey to Hungary. The contingent originally included three persons who were chosen by the Signoria: Piero, as a first rank politician and experienced diplomat; Luca, an educated man with some travel experience already, and the chancellor of the embassy, ser Jacopo Riccardini. They departed from Florence on 22 June 1427 , in the company of a few servants and sixteen horses. On the same day, they received detailed instructions from the chancellor of the Republic in the name of the government, regarding their duties and the general scope of the mission. ${ }^{137}$ An ambassadors' role was primarily to maintain amicable relations with foreign powers and to guarantee undisturbed trade for Florentine merchants in their territories. Recommending Florentine businessmen to the ruler by name was also among their primary responsibilities. ${ }^{138}$ Their mandate most commonly included visits to the most powerful landlords, who in the Hungarian case were members of the royal aula. ${ }^{139}$ In Piero Guicciardini's case, this included a short stay with his brother-in-law, the Archbishop Da Montebuoni. Ambassadors most commonly resided in Hungary for several weeks or months. Piero himself, according to the registers of the chancellery, spent 108 days in the service

137 'Nota et informatione a voi Piero di messer Luigi Guicciardini e Luca di messer Maso degli Albizzi cittadini fiorentini, ambasciadori del Comune di Firenze di quello avete a fare colla Sancta Maiesta del serenissimo et gloriosissimo principe et signore messer Sigismondo [...]'. ASF, Signori, Legazioni e Comissarie 7. fol. 76v.

138 '[... [la comunità nostra et i nostri cittadini et mercatanti alla Suprementia Reale raccomanderete.' ASF, Signori Legazioni e Comissarie 7. fol. 77r.

139 Andrea might have had the occasion to build personal contacts with them; these later on might have facilitated his son's attempt to set foot in Hungary. '[... All'ottavo capitolo che comincia al traccio visiterete e saluterete i signori di Ungheria et facemolo secondo la nostra possibilità [...]'. The ambassadors' answer to the Signoria's instructions on 21 July 1396, confirming that they had visited several dignities in Hungary. ASF, Dieci di Balia, Relazioni di Ambasciatori 1. fol. $20 \mathrm{v}$. 
of the Signoria, from 16 June 1427 through 31 October $1427 .{ }^{140}$ Thanks to Luca's ledger, it is also possible to calculate the approximate costs of an ambassadorship of this kind, which might have been commensurate with the price of a nice house in the Florentine city centre. To cover his travel expenses, Luca received 200 Florentine golden florins from the Dieci di Balìa, the temporary governing body of the Florentine state. ${ }^{141}$ From this sum, the ambassadors were expected to pay for their accommodation, meals, the salary of their servants, passage, supply for their horses, and the small gifts they purchased for their hosts. Beyond this budget the ambassadors were entitled to collect their salaries upon their return to Florence, stipulated on the basis of the length of the mission. ${ }^{142}$ In 1376 , the heirs of Bene di Jacopo del Bene demanded his salary, which amounted to 3 florins, 19 soldi, and 8 denari per day. ${ }^{143}$ Fifty years later, in Piero di Luigi Guicciardini's case, this amount was 4 golden florins.

One of Piero's letters gives us a sense of how an ambassadorial audience with a king took place. In this letter, he describes that after having learned about the King's whereabouts in a camp near the southern borders of the Kingdom, set up in the view of a battle against the Ottomans, he traveled there on horseback, maybe without the rest of his company. After his arrival, Piero was accommodated in the tent of a baron, a friend of the Archbishop Da Montebuoni. Then two knights escorted him to Sigismund's tent. During the audience, held in the presence of the Archbishop Da Montebuoni, the Archbishop of Esztergom, the Bishop of Veszprém, and other barons and royal familiares of Florentine origins, Piero was commanded to sit at Sigismund's feet. Following the formalities, the King ordered him to speak about the reason for his visit, and the King answered his questions in Latin, as Latin would have been one of Sigismund's native languages, along with German and Hungarian. ${ }^{144}$ After his visit to the King's tent, Piero was invited to

140 ASF, Signori, Dieci di Balia, Otto di Pratica, Legazioni e Commissarie e Responsive 8. fol. $87 \mathrm{v}$.

141 ASF, Signori, Dieci di Balìa, Otto di pratica, Legazioni e Commissarie, Missive e Responsive 5. fol. 21 .

142 It is not entirely clear whether or not the budget they had received before their departure was part of their salary; most probably it was not. For the register containing ambassadors' salaries see: ASF, Signori, Dieci di Balìa, Otto di Pratica, Legazioni e Commissarie 8.

143 For documents regarding this embassy see: ASF, Del Bene 50.

144 ' [...] A dì 16 s'aopero tenuto che passamo e venimo nel champo del re e si montano a Ucipadilione 'uribarone, amicho di messer l'arcivescovo [...] il re mandò per me due chavaleri bene acompagnati e chosì mi rapresentai alla sua maestà fatta le debite reverenzie volle ch'io sedessi a piedi suoi a presenzia del archivescovo di Strighonia e de altri; vescovo Da Montebuoni e del vescovo di Vesprimo e di più baroni e gran Dio volle che Filippo del Bene fosse presente Lionardo 
Archbishop Da Montebuoni's place. The Archbishop sent for Filippo di Giovanni del Bene before letting his relative speak. Piero, on the Signoria's order, recommended Filippo and Lorenzo di Rinieri Scolari to his brotherin-law, who, in response, graciously recalled the memory of the Spano. ${ }^{145}$

It is not clear whether after his visit to the King's camp Piero returned to Florence. But we find him again in Hungary the next spring, when he acted as witness for one of the documents issued in the name of the $\mathrm{Da}$ Montebuoni brothers. ${ }^{146}$ Long diplomatic missions gave ambassadors the opportunity to get actively involved in the life of the resident Florentine community. Following Pippo Scolari's death, several Florentines fell out of favour with the King. Piero's participation in the negotiation between the Signoria and Sigismund regarding the mistreatment of Florentines in Hungarian territory was one of the main reasons for his stay. ${ }^{147}$ As we have already seen, among the captured merchants was Piero's in-law, Gianozzo di Giovanni Cavalcanti, as well. ${ }^{148}$ During his days in Hungary from April 1428 at least until 10 August 1428, Piero addressed three letters to the consuls of the Merchants' Guild in which he stated Gianozzo's case. ${ }^{149}$ Given the seriousness of the situation, one might ask if Piero's return may have been suggested by the Archbishop, who actively helped the ambassador in carrying out his mission..$^{50}$ Piero, as one of the executors of Matteo Scolari's

di Nofri, Lorenzo Scolaro e Simone Milanesi mi chomando chio dicessi quello avevo a parlare $[\ldots .$.$] e rispondendo con gran prudentia a tutte le parti chome se io gli avessi sposto in tedescho o$ in unghero che sono le sue naturali lingue e d'uno latino apertto che ancho io l'ò 'ntendea bene disse avea molto acetta l'ambasciate de fiorentini.' ASF, Signori, Dieci di Balia, Otto di Pratica, Legazioni e Commissarie, Missive e Responsive 7. fol. 5 r.

145 ASF, Signori, Dieci di Balia, Otto di Pratica, Legazioni e Commissarie, Missive e Responsive 7. fol. $7 \mathrm{v}$.

146 '[...] Actus in confinibus Hungarie in terra seu villa contra prope Danubium, presentibus Petro domini Loysi de Guicciardinis [...]'. ASF, Diplomatico, Normali, Rinuccini, 04/o2/1427.

147 The Florentine chancellery also sent diplomatic letters to the King, asking for Giovanni and Niccolò Lamberteschi's release. ASF, Signori, Missive, I. Cancelleria 32. fols. 65r-v, 178v-179r. 148 See the ambassador's two letters to the Calimala guild. ASF, Corp. Rel. Sopp. 78.326. fols. 337 r-v. A year later, the Florentine chancellery even sent diplomatic letters to the relator of Gianozzo's case. ASF, Signori, Missive, I. Cancelleria 32 . fols. $5^{2 v-53 r . ~}$

149 On 10 August 1428, Piero was still at the borders of the Kingdom, probably in the King's camp. ASF, Signori, Dieci di Balia, Otto di Pratica, Legazioni e Commissarie, Missive e Responsive 7. fols. 2ov-21r.

150 The diplomat used the service of the Archbishop's servants. '[...] Ingegnero io e Piero avere uno o due famigli di messer l'arcivescovo di Montebuoni.' Letter of the ambassadors to the dieci di Balia. ASF, Signori, Dieci di Balia, Otto di Pratica, Legazioni e Commissarie, Missive e Responsive 7. fol. 4v. (18/08/1427) The Archbishop had even provided him with commercial credit during his journey. 'Item mi trovo debitore di messer Giovanni, arcivescovo di Colloci de Buondelmonti di ducati 80 viniziani. Item mi truovo debitore di Nicholo di messer Andrea da 
testament, might have had other tasks in Hungary, which alludes to the fact that the consuls of Merchants' Guild who were responsible for Gianozzo's case, as well as executors of Matteo's testament, might have also demanded his return to Hungary. ${ }^{151}$ In addition, this reinforces the earlier observation that diplomatic and private interests went hand in hand when appointing ambassadors to foreign powers.

Isabella Lazzarini maintains that prolonged ambassadorships might have led to the shift from high-profile aristocrats or bishops at the head of diplomatic contingents to professionals. ${ }^{15^{2}}$ Riccardo Fubini has described and analysed in more detail the ways ambassadorial practices worked in the second half of the fifteenth century, addressing the issue of diplomatic career models in the Florentine elite. ${ }^{153}$ In light of these later studies, Piero might have represented the earliest of those professional politicians who later started to gradually replace international merchants performing in diplomatic capacities after the fall of the Albizzi regime. ${ }^{154}$

\section{The Albizzi Family}

The Scolari brothers, through their social ties, developed relations with the highest circles of the leading Albizzi faction. In 1426, when Francesca di Matteo Scolari was only a toddler, Pippo or maybe Matteo himself arranged her engagement with Rinaldo degli Albizzi's son, Giovanni (b. c. 1411). ${ }^{155}$ This event marked the consolidation rather than the beginning of political cooperation between the two families.

The history of the Albizzi family goes back to twelfth-century Arezzo, when their ancestor of German origins settled in the city. By the middle of the thirteenth century, his descendants had moved to Florence where the Albizzi grew into one of the most sizeable lineages. ${ }^{156}$ In 1378 , the Estimo mentions 26 Albizzi households, all located in the gonfalon of Chiavi, overwhelmingly

Montebuoni in fi. 67 per paghe di fi. 600 di Monte di Pisa che ho prese delle sue.' ASF, Catasto 335. fol. 579v. See Piero's tax declaration.

151 See the copies of Piero's letters. ASF, Corp.Rel. Sopp. 78. 326. fols. 337r-v.

152 Lazzarini, Communication and Conflict, pp. 125-135.

153 Fubini, 'Diplomacy and Government', pp. 25-48. Ibid, 'Classe dirigente ed esercizio della diplomazia'. Ibid., Italia quattrocentesca, pp. 185-35o. Ibid., 'L'istituzione diplomatica e la figura dell'ambasciatore'.

154 On the rise of the resident ambassador see: Fletcher, Diplomacy in Renaissance Rome.

155 Rinaldo mentions, upon his visit to Hungary, that he was a new relative to Pippo Scolari. Commissioni di Rinaldo degli Albizzi, III. p. 589 .

156 For a detailed genealogy of the lineage, see: Fabbri, 'Opus novarum gualcheriarum'. 
in the Via San Pier Maggiore, which was also called Borgo degli Albizzi, referring in this way to its inhabitants. Over the course of their regime, the Borgo degli Albizzi remained the lieu de puvoir of the lineage. ${ }^{157}$ In 1433, they had 22 households, including 143 family members registered in the Catasto. The total assets declared by the entire lineage included 59,882 florins. However, seven households paid composto, which shows that there were considerable differences among the nuclear families in terms of wealth.

Rinaldo's father, messer Maso di Luca (1343-1417) was a first rank politician and the leader of the dominant Albizzi faction. Between April 1383 and February 1415, there were 334 speeches registered under his name in the volumes of the secret councils. ${ }^{158}$ If Maso had ever developed any connection either to the royal court in Hungary or to the Scolari, we do not know. Only one of his distant relatives, Angelo di Berto degli Albizzi, appears in Hungarian sources. In 1391, he was already a citizen of Buda when he sold his house to Miklós Kanizsai, Master of the Treasury. ${ }^{159}$

\section{Rinaldo di messer Maso degli Albizzi (1370-1442): The Political Ally}

Among messer Maso's offspring, both Rinaldo and Luca (1382-1458) were appointed as ambassadors, in the consecutive years of 1426 and 1427 , to represent the Florentine state in Buda. Luca did not become a commited politician; his name appears only 26 times as a speaker at the secret councils. ${ }^{160}$ Rather, he devoted himself to traveling and writing, which might explain his election to an ambassadorship.

Instead it was Rinaldo, the eldest, who inherited their father's political influence and, following messer Maso's death in 1417, emerged as one of the leaders of the faction in cooperation with Niccolò da Uzzano. Niccolò himself had economic interests in Hungary at least as early as $1394 \cdot{ }^{161}$ After Niccolò's death in 1431, all power was concentrated in Rinaldo's hands. By that time, he grew into a very experienced politician who held 288 public speeches at the secret councils between September 1407 and December 1433. He was

157 In 1433, out of 22 households 20 were located in the Borgo degli Albizzi.

158 ASF, CP vols. 22-43.

159 Zsigmondkori oklevéltár, I. doc. 1921.

160 ASF, CP vols. 38-50. Between May 1414 and August 1432. CP vols. 42-50.

161 He set up a company with Francesco Federighi and Giovanni Tommasi and sent as their agent to Hungary, Agostino di Paolo Marucci. ASF, Signori, Missive, I. Cancelleria 24. fol. $121 \mathrm{r}$ (28/03/1394) See the Signoria's other letter to Sigismund. Signori, Missive, I. Cancelleria 24. fols. 109v-110r. (09/02/1395), 154r-v. (12/og/1395). Agostino was an ad-hoc speaker at the meetings of the secret councils. ASF, CP 16. fol. 104r (11/03/1379); CP 17. fol. 72v. (06/08/1379). 
also the most significant diplomat of the Florentine state; after 1399, he was dispatched by the Signoria to foreign courts on numerous occasions. ${ }^{162}$

The Borgo degli Albizzi, that is, the Via San Pier Maggiore, turned into the headquarters of the faction over the course of these decades. In the 1427 census, there were at least twelve Albizzi households that kept houses on that street. ${ }^{163}$ Many of them were also found in the neighbouring area, like the Via Albertinelli. Besides members of the lineage, the Albizzis' most important political allies clustered in that area: the Guadagni brothers, the Infangati brothers, the Altoviti, Piero di Bernardo della Rena, as well as the Scolari. ${ }^{64}$ Rinaldo di messer Maso degli Albizzi kept his family home about halfway from the Via del Proconsolo to the San Pier Maggiore Church. ${ }^{165}$ His second neighbour was Piero di Bernardo della Rena. ${ }^{166}$ Vieri di Vieri Guadagni lived next to the Albergo dalla Corona, just opposite the Scolari palace. ${ }^{167}$ On the other side of the Albergo, Antonio di Catellino Infangati kept his home, where his brother Baldinaccio also stayed during his Florentine visits. ${ }^{168}$ Next to the Scolari palace, on the corner with the Canto de' Pazzi - that is the Via del Proconsolo - was Andrea Scolari's house where his sister lived. The building was later turned into what is today the Pazzi palace. ${ }^{169}$ The Altoviti did not live on the same street, but they did own a house there. ${ }^{170}$

The Scolari moved to the Borgo sometime before 1410, probably because of a conscious choice to strengthen their political alliance with the Albizzi by means of a shared neighbourhood. The strong connections between

162 Commissioni di Rinaldo degli Albizzi. Brucker, The Civic World of Early Renaissance Florence, pp. 450-453.

163 Antonio di Tedice. ASF, Catasto 80. fol.7v. Pagolo di Piero. Catasto 8o. fol. 141v. Giovanni di Piero. Catasto 8o. fol. 165v. Giovanni di Tedice. Catasto 80. fol. 169v. Niccolò di Gentile. Catasto 8o. fol. 206r. Francesco di Niccolaio. Catasto 80. fol. 341r. Luca di Pagolo. Catasto 8o. fol. 421 r. Stefano di Pagolo. Catasto 8o. fol. 466v. Piero di Filippo. Catasto 8o. fol. 512r. Matteo di Piero. Catasto 8o. fol. 596r. Luca di m. Maso. Catasto 8o. fol. 45v. (Piazza di San Piero Maggiore).

164 Kent, The Rise of the Medici, Appendix I.

165 'Una casa posta nel Borgo degli Albizi, dove habito con la mia famiglia e colla masserizia, da primo via, da secondo Piero e Bartolomeo della Rena, da terzo via e da quarto discendenti di Piero di Filippo degli Albizzi, popolo di San Piero Magiore di Firenze, passa nella via di dietro e confina di là con Antonio di Tedice degli Albizi.' ASF, Catasto 59. fol. 852r.

166 For Bernardo's house see: ASF, Catasto 8o. fol. 137r.

${ }_{167}$ See the tax declaration of Vieri's heirs, submitted in 1427: 'Una chasa posta nel popolo di Santo Brocholo, che da primo la Via di Porta San Piero, sechondo l'Abergho dalla Chorona, terzo rede di Poldo de'Pazzi, quarto vescovo di Fiesole, quinto Francesco Gherardini, nella quale abitiamo [...]'. ASF, Catasto 8o. fol. 904r.

168 'Una chasa a lato all'Albego alla Corona [...]'. ASF, Catasto 80. fol. 12v.

169 'Una chasa a lato al palagio di messer Matteo [...]'. ASF, Catasto 8o. fols. 599r, 395r.

170 Rinaldo di Leonardo Altoviti had a house there. ASF, Catasto 81. fol. $381 \mathrm{v}$. 
the two families are also illustrated by the fact that Rinaldo even acted as legal representative on Pippo's behalf. ${ }^{171}$ The establishment of political ties probably went back years before the engagement between Rinaldo's eldest son, Giovanni, and Francesca di Matteo Scolari. Pippo himself might have negotiated the terms around 1426 and part of the extraordinarily high dowry of 3300 Florentine florins was deposited for the Albizzi. ${ }^{172}$ In fact, Rinaldo's visit in an official capacity in Hungary served both public and private interests, and Pippo's support and the alliance with Sigismund would have considerably reinforced the position of the Albizzi faction. ${ }^{173}$

The year 1426 was important in Florentine domestic politics. The war against Filippo Maria Visconti financially exhausted both the state and its citizens, and by the summer they reached the point when they were reluctant to discuss fiscal problems at the secret councils. ${ }^{174}$ Because of the highly contested situation, there were more speeches registered at the meetings in 1426 than in any other years. ${ }^{175} \mathrm{~A}$ good number of them were delivered at special commissions, the Pratiche, which were called at least $3^{2}$ times that year. ${ }^{176}$ As Dale Kent has suggested, involvement in the Pratiche might be a key in defining the political elite in Florence during the Albizzi regime. ${ }^{177}$ The increased number of Pratiche during the 1420 s was a clear sign of the elitist structure of the regime and an indication that decisions were often made with the involvement of only a restricted group of citizens.

171 In July 1426, Rinaldo also acted as procurator on Pippo's behalf against Jacopo e Massaiozzo di Giglio Gigli, bankers of Andrea Scolari. ASF, Mercanzia 7114bis. (18/o6/1427).

172 In 1427, the tax declaration of the Scolaris' heirs mentions 2000 Florentine florins deposited for the Albizzi. 'Messer Rinaldo degli Albizzi de'dare fiorini 2000 àne in deposito a 5 per 100 per la dota della Checcha, figliuola di messer Matteo Scholari e dona di Giovanni di messer Rinaldo, fiorini 2000.' ASF, Catasto 59. fol. 874v. See Rinaldo degli Albizzi tax return, submitted in 1431: 'Truovomi avere in diposito da messer Filippo Scholari per la dota della Checcha, sua nipote la quale debba essere moglie di Giovanni mio figliuolo fiorini dumilla denari, a 5 per cento, con certe condizioni come potete vedere, fiorini 2000.', Catasto 386 . fol. $687 \mathrm{r}$.

173 Rinaldo had a servant from Zagreb, whom he might have brought with him on his way back from the Kingdom of Hungary. ASF, Catasto 386 . fol. 688r.

174 Pagolo Carnesecchi, one of the most significant merchants operating in Hungary, said: 'Excusando traditionem consiliariorum, quia materia odiosa est et cives pecuniis sunt exhausti.' ASF, CP 46. fol. 111v. Published: Brucker, The Civic World of Early Renaissance Florence, p. 472. About the period in general: Ibid., pp. 472-507.

175930 speeches between 2 January and 29 December. ASF, CP 46. fol. 104r-CP 47.fol. 34 r. 176 ASF, CP 46. fols. 114v (06/02), 143r (05/05), 143r (06/05), 146v (14/05), 157r (23/05), 158v (04/06), 164V (21/o6), 166r (26/o6), 173r (17/07), 174v (24/o7), 180v (30/o7), 183v (o9/o8), 188r (16/o8), 193v (23/08), 196 (30/08); 47. fols. 1v (02/o9), 2v (03/09), 3v (04/o9), 7r (10/o9), 8r (11/o9), 10v (17/og), 11r (22/og), 12v (28/og), 2or (o6/11), 23r (12/11), 34r (29/12).

177 Kent, The Florentine Reggimento. 
Considering the persons in the present study, this group included: Rinaldo degli Albizzi, Filippo di Giovanni Carducci, Antonio di Piero di Fronte, Piero di messer Luigi Guicciardini, and Ridolfo di Bonifazio Peruzzi. Among them, Pietro Guicciardini and probably also Filippo Carducci shall be considered as apparent Medici friends. ${ }^{17}$

In 1426, key figures of the Albizzi faction died, including the three Scolari and Vieri di Vieri Guadagni. They were followed a couple of months later by Antonio di Piero di Fronte and Pagolo di Berto Carnesecchi. After Da Uzzano's death in 1431, which made Rinaldo the sole leader of the faction, Rinaldo had lost his most important foreign supporters, including King Sigismund and the Florentine community in Hungary. At that point, though, the rhetoric was still incomparably higher on the Albizzis' side. Rinaldo himself spoke 288 times at the secret councils. Meanwhile Cosimo de'Medici (1389-1464) delivered only sixteen speeches during the studied period, and Cosimo's father, Giovanni di Bicci (1360-1429) gave 96. ${ }^{179}$ Giovanni and Cosimo rarely participated in the Pratiche. ${ }^{180}$

The fall of the regime, as John F. Padgett claims, might have been due to other differences that manifested in the economic potential and networking strategies of the two factions and their leaders. ${ }^{181}$ Over the course of the fourteenth century, the Albizzi lineage is considered the leader among those engaged in wool manufacturing in Florence. ${ }^{182}$ But Rinaldo's father, Maso di Luca, received one-fourth of the fulling mills in the division of the patrimony, in $1373 \cdot{ }^{183}$ In fact, in 1427 , his sons' names do not appear among the ones holding shares in the fulling mills. ${ }^{184}$ Rinaldo, according to the testimony of his Catasto declarations, was not engaged in any large-scale business activity and we do not find any business firm under his name in the 1433 Catasto. In the early 1430 , only his sons had shares in various silk and wool manufacturing companies. Maso invested in a silk firm with Matteo and Ormanno degli Albizzi. ${ }^{185}$ Meanwhile Tobia and Giovanni ran a

178 Filippo's two brothers, Bartolomeo and Niccolò, were filo-Medici politicians. Kent, The Rise of the Medici, Appendix I-II.

179 Giovanni spoke between 1398 and 1427. ASF, CP vols. 32, 33, 35, 36, 37, 38, 39, 40, 41, 42, 43, $44,45,46,47$.

180 Giovanni six times, between 1414 and 1426 . ASF, CP 42 fol. 185 r, 44. fols. 18v, 117v. CP 46. fols. 1r, 7r, 16v. Cosimo only once, in 1425. CP 46. fol. 86r.

181 Padgett and Ansell, 'Robust Action and the Rise of the Medici'.

182 Hoshino, L'Arte della Lana in Firenze, pp. 305-327.

183 Fabbri, 'Opus novarum gualcheriarum', pp. 544-546.

184 Hoshino, Industria tessile.

185 ASF, Catasto 386. fol. 683v. 
wool workshop with Andrea de'Pazzi. ${ }^{186}$ Rinaldo's wealth, therefore, was of ancient heritage, based mainly on his extended properties in the Florentine countryside and not on large-scale business activity. ${ }^{187}$

The Medici firm, on the other hand, was a major player in international banking and hard to avoid for anyone seriously engaged in trade at this period. Their branches in Florence, Venice, and the papal court grew into indispensable intermediaries between Florentine companies and their traveling agents. This significant contrast in their business profiles resulted in an impressive difference of wealth between the two leaders. In 1433, Cosimo and Lorenzo di Giovanni de'Medici declared 73,823 florins of total assets, while Rinaldo declared only 12,802 florins, and his brother Luca declared 8553 florins of total assets. ${ }^{188}$ Nevertheless, in September 1433, Rinaldo was able to achieve Cosimo's exile, but exactly a year later Cosimo was called back to the city by his followers. ${ }^{189}$ Consequently, he sent several members of the Albizzi faction to exile, including the Scolaris' old friends Rinaldo and his family, Simone and Tommaso di Lapo Corsi, Ridolfo di messer Bonifazio Peruzzi, and Bernardo di Vieri Guadagni. ${ }^{190}$

7 The Guadagni Family

The social alliance between the Scolari and the Guadagni families was consolidated in 1420 with the marriage between Matteo's eldest daughter, Caterina, and Vieri di Vieri Guadagni's son, Francesco (b. c. 1400). ${ }^{191}$ The

186 The workshop is mentioned in their declaration, submitted in 1431. Rinaldo's declaration: 'Giovanni, mio figliuolo mi de' dare fiorini 4000 denari, i quali tiene nel corpo della compagnia di Thobia, mio figliuolo e compagni lanaiuoli [...]'. ASF, Catasto 386 . fol. 68ov. Their third partner was Matteo di Piero di Banco. Catasto 478. fol. 19r.

187 Hoshino, L'Arte della Lana, pp. 325-326.

188 ASF, Catasto 497. fol. 177r. (Cosimo and Lorenzo de'Medici), Catasto 499. fol. 655r. (Rinaldo degli Albizzi), Catasto 499. fol. 484v. (Luca degli Albizzi).

189 In November 1434, at the secret councils, Luca di messer Maso degli Albizzi, Cosimo de'Medici, Neri di Gino Capponi, and Niccolò Valori said, 'Lo errore è chiaro che comminciò nel 1433 del mese di septembre. Et quello errore ha partorito quest'altro di quelli che ànno voluto fare contro alla Signoria e contro al palagio, puniscasi quelli che ànno errato nell'uno caso, nell'altro a cciò che esino exemplo agli altri di non commectere simili delicti,' and ASF, CP 50. fols. 204 r-v.

190 Rinaldo went into exile to Naples or Trani. Francesco Guadagni went to the Stinche. Ridolfo went to Aquila. For the exiled families, see: Brown, 'Insiders and Outsiders', Appendix. Kent, The Rise of the Medici, Appendix II.

191 The Guadagni received a dowry of 3300 Florentine florins. ASF, Guadagni 14. 15. One of Matteo Scolari's brothers-in-law, Antonio di Catellino Infangati, commemorated the event in his private account book: 'Ricordanza chome a honore di Dio e di Madona Santa Maria e di tutta 
Guadagni was an ancient lineage, but of popolani origins which traced its roots to the twelfth century in Florence. ${ }^{122}$ They were also supporters of the Guelph Party. ${ }^{193}$ The lineage was not particularly extended in the fourteenth century. In 1378, they had nine households dispersed throughout the city. Already at that time, Vieri's family, who were registered under the name of Migliore di Vieri di Migliore, lived in the Borgo San Pier Maggiore (Borgo degli Albizzi). ${ }^{194}$ In 1433, only four households submitted a declaration, and among them, three were headed by Vieri di Vieri's sons. ${ }^{195}$ They counted 26 family members and declared all together 18,503 florins of total assets. Two of the households paid catasto: 7 florins, 29 soldi, 11 denari, and two others only composto. Prior to 1382, the sole member participating in the meetings of the secret councils was Migliore. ${ }^{196} \mathrm{He}$ and a few other members of the family occasionally held city offices as well. ${ }^{197}$ No sources have come to light which would suggest an earlier connection between the family and the Kingdom of Hungary.

\section{Vieri di Vieri Guadagni (c. 1370-1426): The Banker}

The in-law Vieri di Vieri's name appears for the first time as a speaker at the secret councils in 1397, which suggests that he was about the same age as the Scolari brothers. ${ }^{198} \mathrm{He}$ enrolled in three different guilds: Merchants', Moneychangers' and Wool Guilds, securing his election for a number of city offices. He served a few times as consul of the Wool Guild and covered on many occasions the office of Standardbearer, as well as other city magistrates. ${ }^{199}$ With his active participation in politics, he became the most passionate

di cielestiale corte di Paradiso la Chaterina figliuola di messer Matteo Scholari n'andò a marito a dì 16 di gugnio 1420 al figluolo di Vieri Ghuadangni cioè a Francescho suo figluolo maggiore a chui i Dio dia buona ventura e si a lui e si a lei sempre prosperando di bene in meglio e durando insieme lungho tempo che chosì piaccia a Dio che sia.' ASF, Corp. Rel. Sopp. 97 . 13. fol. 112v.

192 Passerini, Genealogia e storia della famiglia Guadagni.

193 In the 138 os, Migliore di Vieri Guadagni, on behalf of the Guelph Party, took part in the confiscations. ASF, Capitani di Parte Guelfa, Numeri Rossi 57. fols. 57r, 71r.

194 ASF, Prestanze 369. fol. 74v.

195 Bernardo di Vieri. ASF, Catasto 499. fol. 141r; Francesco di Vieri. Catasto 499. fol. 29ov; Migliore di Vieri. Catasto 499. fol. 507r; Matteo. Catasto 499. fol. 537r.

196 For his speeches, see: ASF, CP vols. 2-13, (1358-1375).

197 Migliore held the office of Standardbearer and Twelve Good Men: ASF, CP 2. fol. 86r. (15/05/1359); 7. fol. 42v. (16/09/1365)

198 ASF, CP 32 . fol. 96r. In 1391, he was mentioned as minor in the election for city offices. Online Tratte of Office Holders record n. 110776.

199 ASF, Arte di Calimala 6. fol. 8r. (1407, renewal of his matriculation). In 1418, he was elected to consul of the Wool Guild. ASF, Arte della Lana 543. fols. 35v, 53r-v, 55v. Between 12 June 1403 
supporter of the Albizzi faction. Between February 1397 and May 1426, there were 146 speeches registered under his name, and he took part in the Pratiche at least ten times. ${ }^{200} \mathrm{He}$ was involved in Florentine diplomacy as well, by representing the Signoria in foreign courts at various times as an ambassador, including official visits to Ladislaus of Durazzo in the years 1412-1413. ${ }^{201}$ In 1419, he, Giovanni di Bicci de'Medici, Bartolomeo Valori, and Niccolò da Uzzano were appointed as executors of Pope John XXIII's (c. 1370-1419, elected in 1410) testament, which alludes to his connections to the papal court at this early period..$^{202}$

The pope was Giovanni di Bicci de'Medici's close friend, who gave the Medici bank access to the Apostolic Chamber. ${ }^{203}$ In 1411, when John XXIII nominated Jacopo di Francesco del Bene and Francesco di Giachinotto Boscoli to be depositaries of the Chamber, they were provided with capital by four other Florentine businessmen: Andrea di Lipaccio de'Bardi, Averardo di Bicci de'Medici, and Filippo and Bartolomeo di Giovanni Carducci. As early as 1397, Giovanni di Bicci had operated his own branch in Rome. ${ }^{204}$ Consequently, Giovanni set the headquarters of the bank in Florence and in 1402 opened a branch in Venice. However, during the first of more than two decades of its existence, the branch following the papal Curia was the principal source of profits. From one side, the Medici bank acted as depositary of the Apostolic Chamber, handling funds for the papal treasury, and from the other side, prelates residing in the court also turned to them with their financial businesses. In 1420, after the bankruptcy of Doffo Spini's firm, the Medici gained dominance in the papal finances and following that, until 1443, the depositaries were all Medici men. ${ }^{205}$

As a businessman, Vieri Guadagni probably did not separate himself completely from the Medici faction, and he and his brother might have had

and 6 May 1413, Vieri was mentioned as Standardbearer seventeen times in the registers of the secret councils: ASF, $\mathrm{CP} 35$. fol. $85 \mathrm{r}$, CP 42 . fol. $5 \mathrm{v}$.

200 For his speeches see: ASF, CP vols. 32-46. For the Pratiche he participated in see: $\mathrm{CP}_{3} 6$. fol. 89v. (1403), 41. fols. 144v, 170v, 172v. CP 43. fol. 142r. CP 44. fol. 169r. CP 45. fols. 66r, 133v, 159v, 182v (1424).

201 For examples, see: ASF, Dieci di Balìa, Legazioni e Commissarie 3. fols. 124r, 174r, 176r, 348r. ASF, Signori, Rapporti di relazioni di oratori fiorentini 2. fols. 53v, 6or, 123v, 127r. ASF, Signori, Legazioni e Commissarie 6. fols. 5v, 32v, 35r, (Ladislaus of Naples), 39v, 81v, 94r, 10or. Signori, Legazioni e Commissarie 3. fols. 94r, 105r.

202 However, it appears to have been Giovanni di Bicci who managed the financial side of the testament. Holmes, How the Medici, pp. 376. Cassandro, 'Due famiglie di mercanti', pp. 311-329. 203 Holmes, How the Medici, p. 364.

204 De Roover, The Rise and Decline of the Medici Bank, pp. 36-50.

205 Holmes, How the Medici, pp. 378-379. 
similar plans in establishing a name for themselves as bankers in the papal Curia. The start of his career, though, was different from that of Giovanni di Bicci. He and his brother Bernardo (1369-1433) appear in 1390 as business clients in the account books of Jacopo di Francesco del Bene. ${ }^{206}$ Though they maintained two separate households, their business activities tied them together. In the early 1400s, they owned a retail cloth firm together and ran a wool-manufacturing workshop in the Convent of San Martino. ${ }^{207}$ Their investments in the local wool industry remained important during their lives. Vieri later put money into two separate companies he established, one with Adovardo di Cipriano Giachinotti, Fruosino di Luca da Panzano, and Nofri di Jacopo Cardinali, and the other with Andreuolo di Niccolò Sacchetti and Fruosino di Luca da Panzano. ${ }^{208} \mathrm{He}$ also had shares in a warehouse company, which he ran with Niccolò di Francesco Sacchetti and Niccolò Villani. ${ }^{209}$

Banking, as part of their business profile, might have come later into the Guadagni brothers' lives. In 1414, Bernardo appears - among other Florentines, including Giovanni di Bicci - as a businessman administering funds for John XXIII's treasury. ${ }^{210}$ In 1420 , Bernardo, probably using the profits obtained in the wool industry, set up a merchant banking company with the Cambini brothers, Andrea and Niccolò di Francesco and Adovardo di Cipriano Giachinotti. ${ }^{211}$ They opened branches both in Florence and in Rome. ${ }^{212}$ After a couple of years, Bernardo moved out of the company and in 1424 his partners decided to invest 4000 Florentine florins into the

206 See as examples: ASF, Del Bene 19. fols. 9v, 1or, 32v, 33r, 43v. (libro di commercio di lana, 1390-1392) Del Bene 20. fols. 2or, 9ov-91r. (libro di commercio di lana, 1391-1393). Bernardo also served the Signoria as ambassador.

207 ASF, Arte della Lana 318. fols.45v, 76r, 52r. ASF, Catasto 478. fol. $280 v$.

208 They established the first company in 1425. Adovardo's declaration, submitted in 1427: ASF, Catasto 46. fol. 85 r. The second company was set up in 1422 . Sacchetti's tax declaration, submitted in 1427: Catasto 29. fols. 7v-8r, 9r. The tax declaration of Vieri di Vieri Guadagni's heirs, presented in 1427: Catasto 57. fols. 906v-921r. ASF, NA 681. fol. 2 r.

209 See his son Bernardo's declaration from 1427. ASF, Catasto 56. fol. 503r. In 1413, Matteo Scolari made a deposit for Niccolò Serragli, Lorenzo di Giovanni Strozzi, and Niccolò di Matteo Villani. ASF, Monte ser. II. 1806. fol.144V.

210 Archivio Segreto Vaticano, Registri Vaticani, vol. 346. fols. 159r. (he appears with Giovanni di Bicci), fol. $167 \mathrm{r}$.

211 Tognetti, Il banco Cambini, pp. 36-37.

212 The Cambinis' partnership(s) appear also in the account book of the Apostolic Chamber, dated to 1423. 'Die xxii dicti mensis prefactis dominus Antonius thesaurarius habuit, recipuit dicto Bartholomeo de Bardis depositario nomine Camerae Apostolice ab Adoguardo Iachinocti, Nicolao Cambii et sociis mercatoribus Florentinis florenos auri de Camera ducentos quos Camerae Apostolice mutuaverunt a omnio rehabendi.' Archivio Segreto Vaticano, Camera Apostolica, Introitus et exitus 379. fol. 114v. 
more prestigious company of Vieri di Vieri, which operated until Vieri's death. In the 1410 s and 1420s, Vieri kept a local moneychanging table at the Mercato Nuovo. ${ }^{213}$ Vieri's company might have served as one of the most important banks for the Scolari's business; it was also included in Matteo's testament. ${ }^{214}$ Also, the Archbishop of Kalocsa and his brother Niccolò di messer Andrea da Montebuoni used their services. ${ }^{215}$ In the balance of Vieri di Vieri Guadagni's company in Rome, his heirs declared a considerable number of debtors of foreign origins, among them many from the Kingdom of Poland. ${ }^{216}$ Furthermore, an entry in the account book of the Apostolic Chamber, datable to 1426, shows that the Guadagni bank was an intermediary between the Chamber and the collectors operating in the Kingdom of Poland. ${ }^{217}$ This might allude to the fact that the Guadagni bank developed interest in that part of Europe and also that the Florentine merchants working in the Kingdom of Hungary connected other neighbouring destinations to their international network of trade. ${ }^{218}$

At his death in August 1426 Vieri was commemorated by Pagolo di Matteo Petriboni as one of the most respected citizens of his time. ${ }^{219}$ Among his sons, Francesco, Caterina Scolari's husband, continued his father's activity in the banking business as well as the cultivation of the in-law ties with the Scolari. ${ }^{220}$ He acted a few times as a legal representative on Matteo Scolari's behalf and managed his business credits and debts on Pippo's commission. ${ }^{221}$

213 See the numerous entries in the account books of Lazzaro di Giovanni di Feo Bracci. AFL, 3340. fols. 11r, 12r, 46v. (1415)

214 'Antonius Pieri Frontis in florenos auri quingentis pro ut constat pro libros Vieri Guadagni. Baldinaccius domini Salicis de Cavalcantibus pro ut constat pro libros dicti Vierii. Spinus Azolini pro ut constat pro libros dicti Vierii et Nicholai Johannis del Bellaccio.' ASF, NA 5814. fol. 271r. In 1428, Vieri's sons sued the Scolaris' heirs for business debt at the Merchant Court. ASF, Mercanzia 7117. fols. $312 \mathrm{v}-314 \mathrm{r}$.

215 See the case between tra Benedetto di ser Lando di messer Tommaso da Cena and the heirs of Vieri Guadagni's bank. ASF, Guadagni 14. 10. fols. 1r-11v. (1429)

216 See the balance: ASF, Catasto 57. fols. 920-922v.

217 'Dalla Chamera Apostolicha a dì ultimo detto fi. sei cento ebbi dalla compagnia delle rede di Veri Guadagni e compagni sono per conti paghano per nome di messer Jacomino de Rosti collettorre in Pollonia per denari rischossi in detta collettoria. fi. vi cento.' Archivio Segreto Vaticano, Camera Apostolica, Introitus et Exitus 384. fol. 2r. (30/o9/1426).

218 This might explain the modest number of references to diplomatic contacts between Florence and the Kingdom of Poland. Bettarini, 'The New Frontier'.

219 Petriboni and Di Borgo Rinaldi, Priorista, p. 190.

220 See a business claim between Simone, Niccolò, and Giovanni di messer Andrea da Montebuoni e Francesco di Vieri Guadagni, regarding the heredity of Pippo Scolari. ASF, Mercanzia 7116. fols. 92v-93r. (22/og/1422).

221 Francesco managed Matteo's deposit at the Merchant Court. ASF, Mercanzia 11781. fol. 81v $(1424 / 25)$. Along with the outstanding debts and credits of the deceased was his competency. 
In 1427, Francesco even declared a business obligation with Baldinaccio di Catellino Infangati. ${ }^{222}$

Even though his name never appears as a speaker at the secret councils, in 1434, his father's close connections to the Albizzi faction resulted in his exile outside the borders of the Florentine state. The Guadagni bank, probably due to this event, disappeared; meanwhile, the Cambini brothers, studied by Sergio Tognetti, had turned their own partnership into one of the most prestigious banks of Florence by the mid-fifteenth century. ${ }^{223}$

\section{The Altoviti Family}

The Scolari and the Altoviti families were connected to each other by double marriage ties. Sometime between 1369 and 1396, Pippo and Matteo's sister Balda (b. c. 1357/5-) married Caccia di Palmieri Altoviti. ${ }^{224}$ Later, one of Balda's sons, Martino di Caccia, married Andrea Scolari's niece, Margherita Nardi.

The history of the Altoviti lineage in Florence goes back to the thirteenth century, but they were of popolani origins. ${ }^{225}$ In the late fourteenth century, their lineage, compared to the others studied in this book, was quite extended. In 1378, they had 20 households, located mainly in the gonfalon of Vipera, quarter of Santa Maria Novella. ${ }^{226}$ This number did not change significantly by 1433 , when the lineage numbered 21 households and 91 family members. ${ }^{27}$ Out of these households, six paid only composto, but

'Questi sono i danari che Francescho di Vieri Ghuadagni e fratelli ànno avuti e ricevuti per messer Matteo Scholari e lle sue rede [...] andò Francescho in Ungheria alo Spano e portogli chonti con mostradegli che restava avere da messer Matteo Scholari fiorini 2600 [...]'. ASF, MAP filza 150. doc. 17. fol. 19r.

222 'Baldinaccio di Chatellino Infanghati e Francesco Ghuadagni cioè Francecso è obrighato pel detto Baldinaccio fiorini 663 s. 14 d. 6.' This entry is included in the tax return, submitted in the name of Vieri's sons, and entitled 'Rede di Vieri Ghuadagni e compagni, 1427. Debitori del libro delle merchatantie segnato J, questo dì xii di luglio de libro detto'. ASF, Catasto 57 . fol. 913 .

223 Tognetti, Il banco Cambini, pp. 117-264.

224 The marriage was mentioned by Litta, Passerini, I Buondelmonti, tavola XII. ASF, Manoscitti 519, inserto 4. fol. 3 r. I have calculated the date of their marriage on the basis of the birthdate of their son, Martino.

225 Passerini placed the origins of the family to the twelfth century; however, the family name seems to appear in the documents only decades later. Passerini, Genealogia e storia della famiglia Altoviti.

226 ASF, Prestanze 367. fol. 59v. Prestanze 368. fols. 4V, 5r-v, 7r, 15v, $16 \mathrm{r}$.

227 ASF, Catasto 492, fol. 87v. Catasto 455. fols. 47r, 54r, 118r, 153r, 158r,192r, 202r, 221r, 287r, 318r, 355 r, 381r, 422r, 432r, 444r, 446r, 455r, 496r, 516r, 722r. 
the majority had catasto; however, because of some missing data the total assets of the lineage cannot be calculated. Members of the lineage were also very active politically, and we find their names among the speakers of the secret councils at the very beginning of its history. ${ }^{228}$ Several Altoviti appear to have covered city offices before and during the studied period. ${ }^{229}$ However, Caccia di Palmieri's name is not among the office holders or among those politically active. Similarly, there are no references to whether his family was connected in any way to Hungary before Pippo's entrance into the local political elite.

\section{Leonardo and Martino di Caccia Altoviti (1396-a. 1439): The Heirs}

Because of Caccia's complete absence from the guild matriculations and from the lists of office holders and speakers at the secret councils, it is no surprise that we do not find his sons' names in the abovementioned sources. Their businesses, if they had any, remain undocumented by the records of the 1433 Catasto. Given all these circumstances, the living conditions of Caccia's family would have been quite modest. Among his sons, Martino was a later child, but we do not know anything about his brother Leonardo.

The earliest source mentioning the Altoviti and the Scolari brothers together is dated to 1412, when the latter accepted Leonardo as their universal heir and gave him shared property ownership over some of their estates in Hungary, including Ozora. ${ }^{230}$ In 1416, the three of them jointly received the privilege from King Sigismund of constructing a castle on their estates. Whether Leonardo ever enjoyed his uncles' donations is unclear, but until that point, he was definitely viewed as their successor.

The Scolari brothers' choice in installing Leonardo as their universal heir might have been influenced by several circumstances. By 1412, the 43- or 44-year-old Pippo, after more than a decade of marriage, probably did not have any surviving offspring. Matteo, who was also in his early forties, had only one daugther. Therefore, the two already middle-aged Scolari might have developed concerns about succession and inheritance. From this point of view, Caccia's sons, although they did not hold the Scolari name, seem to have been the most rational choices. Ensuring the Altoviti brother's line in

228 ASF, CP vols. 1-50. (1349-1434).

229 For example, Stoldo, in the capacity of Standardbearer, was a frequent speaker at the secret councils. ASF, CP 2o. fols. 128r, 131v, 138v, 140v, 141v, 143v, 147r, 148r, 153r, 155r.

230 '[...] nepotus eiusdem heredes et successores [...]'. MOL, DL 87891. Published: Okmánytár Ozorai Pipó történetéhez. III, p. 426. Zsigmondkori oklevéltár, III. doc. 2650. (o9/og/1412). 
the succession might have led Pippo to negotiate a marriage with his cousin, Andrea Scolari, between Caccia's other son, Martino, and Andrea's niece, the daugther of Jacopo Nardi and Constanza di Filippo Scolari (1377-1450). The marriage took place sometime in the early 1420 s, and by 1427 the couple already had several offspring. ${ }^{231}$ The close ties between the Altoviti and their uncles is also exemplified by the fact that Matteo left an annuity of 100 Florentine florins in his testament for Martino's sister Caterina. ${ }^{232}$

However, for reasons unknown to us, Pippo and Matteo changed their previous intention to include Caccia Altoviti's sons in their inheritance. Leonardo died around 1424, which was mentioned in a Hungarian document. ${ }^{233}$ In 1426 one of his sons, Giovanni, appears in Hungarian sources. ${ }^{234}$ Leonardo left a household composed of his widow, Jacopa di Giovanni di Bandino da Filicaia, and three sons, Rinaldo (b. c. 1390), Giovanni (b. c. 1392), and Zanobi (b. c. 1399). ${ }^{235}$ The Da Filicaia were the Scolaris' neighbours in the Borgo degli Albizzi, which might explain the choice of wife for Leonardo. ${ }^{236}$ In 1427, their household owned a family home in the parish of Santa Maria Novella, another house in the parish of San Pier Maggiore, and smaller parcels of lands and vineyards in the countryside. But there is no evidence if Leonardo had ever received any immovable properties from the Scolari.

Similar to Leonardo's heirs, Martino, with his already sizeable family, might have benefited from the benevolence of the Scolari. His wife received a parcel of land from his uncle, Andrea Scolari, but it was hardly enough to provide them with a decent living. ${ }^{237}$ The Altoviti brothers remained excluded from the inheritance and besides that land, none of the Scolari estates were passed on to them..$^{238}$

231 See Martino's tax declaration, presented in 1427. ASF, Catasto 38. fols. 457r-458r. The correction of his declaration: Catasto 297. fols. $35^{\text {r- }} 36$ r.

232 ASF, NA 5814 . fols. $78 \mathrm{v}, 267 \mathrm{v}$. See also the declaration of the heirs. ASF, Catasto 59 . fol. $875 \mathrm{v}$. 233 Sopron vármegye története, II, pp. 77-80. See also: Engel, 'Ozorai Pipo', p. 87, n. 224.

234 Okmánytár Ozorai Pipo történetéhez, IV, pp. 613-616.

235 ASF, Catasto 38 . fol. 622v. His wife's name was reported in the tax declaration of Antonio di Luca da Filicaia. Catasto 8o. fol. $65 \mathrm{v}$.

${ }_{23} 6$ The widow owned some immovable properties in the Borgo degli Albizzi, located next to the house of Piero di Bernardo della Rena. ASF, Catasto 80. fol. $65 \mathrm{v}$.

237 Since the Bishop cared diligently for her sister, it is likely that he was the one to provide Margherita di Jacopo Nardi with a dowry. He also left in his testament a considerable sum of money to Margherita. See Andrea's testament: ASF, CS serie II. 134. fol. 117r. The copy of the document: ASF, Corp. Rel. Sopp. 78. 326. fol. 288r. Margherita's tax declaration, submitted in 1458: ASF, Catasto 812. fol. 52r.

238 Martino's declaration submitted in 1433. ASF, Catasto 445. fols. 318r-319r. 
Pippo's and Matteo's initial plan might have been to keep the family patrimony together in the hands of the Altoviti brothers. Although they later changed their intention, their estate planning was still not at all in conformity with the most common strategy at the time, described by Thomas Kuehn, which emphasized to an extreme patrilinear kinship in inheritance. ${ }^{239}$ Pippo left his estate in Ozora and all of its subject lands in his widow's hands. ${ }^{240}$ Meanwhile, Matteo wished to transmit a considerable part of his immovable properties through the female line.

An essential part of Matteo's strategy was to provide his three daugthers with extraordinarily high dowries of 3300 Florentine florins each. By comparison, Alessandra di Filippo Macigni, offspring of one of the richest families of Florence, brought 'only' 1600 Florentine florins of dowry to her in-laws, the Strozzi. ${ }^{241}$ The dowry of Caterina, the eldest, was paid to the Guadagni, following her marriage on 12 June $1420 .{ }^{242}$ Caterina's testament was issued in 1442, by which she named her sons as her general heirs, thus passing on her father's inheritance to the Guadagni. ${ }^{243}$ The dowry of her younger sister Francesca (c. 1422-1478) had already been deposited in 1426 . Later, Matteo's estate was given to Francesca's husband, Bonaccorso Pitti, and then by him to their offspring. Matteo left the same amount to his youngest, Mattea (b.1424), who died prematurely. This instituted her sister, Francesca, as her legal heir who was entitled to get half of her dowry. ${ }^{244}$ After their father's death, the dowries of the two younger girls were managed by the Magistrato dei Pupilli, as was customary in the case of orphan girls of a certain social status. ${ }^{245}$ Besides their dowries, the three Scolari daughters also enjoyed the income of some of their father's former lands. ${ }^{246}$

239 Kuehn, Heirs, Kin, and Creditors, p. 82. More generally: Chapter 3 .

240 Zsigmondkori oklevéltár XIII. doc. 585. (18/05/1426)

241 Crabb, The Strozzi of Florence, p. 22.

242 ASF, Guadagni 14. 9. fol. 4V.

243 She had three sons: Vieri, Filippo, and Matteo di Francesco Guadagni. ASF, Guadagni 11. 3. fol. 2r. She died probably in 1460, when her son Filippo took over her inheritance. Guadagni 14.1 5. fols. 1r-v.

244 Francesca's declaration, submitted in 1431: 'Item pretende avere ragione nella'redità di detto suo padre per la metà di fiorini 3000 lasciò ala Mattea, sua sirochia nel simile modo perché è morta, non maritata [...]'. ASF, Catasto 385 . fols. $814 \mathrm{v}$.

245 See for example: ASF, Magistrato dei Pupilli 56 . fol. $55^{\text {r. }}$ (1436).

246 'La terza parte degli usufruti d'uno podere posto nell popolo di Santa Andrea a Morgiano, con chasa da lavoratore [...] Item pretende avere ragione nella terza parte degli usufruti degl'infrascritti poderi de quali niente n'à per ora perché si tenghono per creditori di dette rede [...] Uno podere posto nel popolo di Sancto Piero a Ema chon uno palagio e tore e chasa da lavoratore e fornaccie da chalcina luogho detto al Prato. Uno luogho posto nel popolo di Sancto Stefano a Champi luogho detto El fornelo con chasa da signore e cholonbaia e orto murato. Item 
By the restitution of their wives' dowries, Pippo and Matteo Scolari left little possibility for their male relatives to succeed. Therefore, neither the Altoviti nor the Scolari nephews ever inherited any immovable properties in the Kingdom of Hungary or in the Florentine Republic upon Pippo's and Matteo's deaths. Only the estates of their closest uncle, Andrea Scolari, were passed on to the Scolari. This decision might have left Martino Altoviti in a difficult financial situation to the extent that in 1439 one of his sons was forced to repudiate him. ${ }^{247}$

\section{$9 \quad$ The Infangati Family}

Aside from the Altoviti family, the Scolari brothers' closest in-laws were the Infangati, because of the marriage between Matteo and Piera, daughter of Catellino di Baldinaccio Infangati. The history of the lineage was much like the Scolaris': as one of the oldest lineages, they appear in Florentine sources in the twelfth century. They traditionally belonged to the magnates, and they were of Ghibelline loyalties, too; therefore the lineage suffered severe property losses to the anti-magnate and anti-Ghibelline laws. ${ }^{248}$

In 1378, they had six households located mainly in the parish of San Pier Scheraggio, gonfalon of Carro, quarter of Santa Croce. ${ }^{249}$ By 1433, this number was down to three households with sixteen family members. ${ }^{250}$ They reported together 3782 florins of total assets and only one of the households paid catasto of one florin, one soldi, and three denari. ${ }^{251}$ As an ancient magnate lineage, its members never appear as speakers at the meetings of the secret councils, and their names are not registered among those elected

pretende avere ragione nella pigione delle infrascritte chasate e botegha sono in chontesta de chonsoli di Chalimala. Due chasette e una botegha a uso di malischalcho poste nel popolo di Sancto Brocholo apichate alla chasa grande di messer, Matteo suo padre.' ASF, Catasto 385 . fols. $814 \mathrm{r}-\mathrm{v}$.

247 His son Caccia repudiated him. ASF, Ripudie d'eredità 12. fol. 38r. (18/11/1439), Ripudie d'eredità 13. fol. 139v. In 1433, Margherita and Martino had eight offspring, and they paid only composto. ASF, Catasto, 455 . fol. $318 \mathrm{r}$.

248 Lansing, The Florentine Magnates, Appendix.

249 Girolamo. ASF, Estimo 268. fol. 29r. Jacopo di Piero. Estimo 268. fol. 82v. 367. fol. 14r. Miniato di Manetto. Estimo 268. fol. 84v; Piera, widow of Baldinaccio. Estimo 268. fol. 1ov; Giovanni di Catellino. Estimo 268. fol. 11r; Antonio di Manetto. Estimo 268. fol. 11r.

250 Antonio di Catellino. ASF, Catasto 499. fol. 22r. Baldinaccio di Catellino. Catasto 499. fol. 174v. Pagolo di Jacopo. Catasto 489. fol. 46or.

251 The Catasto at this point might not be accurate. 
for city offices either. ${ }^{252}$ However, they were heavily involved in business. In the 1350s, the brothers Baldinaccio and Giovanni di Catellino Infangati, members of the Moneychangers' Guild, were running a firm together. ${ }^{253}$ Around 1364-1366, following Baldinaccio's death, his son, Catellino, renewed the partnership with Giovanni. ${ }^{254}$ By the time he became Matteo Scolari's father-in-law, Catellino had been in the money-changing business for at least thirty years. Piera's dowry of 1000 Florentine florins, by no means of insignificant size, shows that the Infangati had indeed obtained a certain financial stability in business life. ${ }^{255}$ The family seemingly had no earlier connection to the Kingdom of Hungary, but they belonged to the same social strata as the Scolari, which made them an excellent choice for a marriage alliance.

\section{Antonio (b. 1387) and Baldinaccio (b. c. 1395) di Catellino Infangati: The In-Laws}

The marriage between Piera Infangati and Matteo Scolari took place sometime before 1407, which is the approximate birth year of their eldest daughter. Around the same time, the Scolari brothers moved their family home from the Via Panzano to the Borgo degli Albizzi, thus becoming neighbours to the Infangati, who kept houses and workshops just opposite the Scolari palace. ${ }^{256}$ In 1424, after Catellino's death, his two sons, Antonio and Baldinaccio, kept two separate households, though they physically remained residents in the very same paternal house and cooperated closely in business life by continuing their father's profession in the money- changing business. In addition to the wedlock between Matteo and Piero, the in-law ties between

252 Only one member of the family, named Uberto, is mentioned as speaker at the secret councils. ASF, CP 1. fol. 7v. (1349)

253 ASF, Arte del Cambio 44. fols. 68r-v, $180 v$ (1353). For the two brothers as partners, see: Arte del Cambio 14. fol. 37v (1359, libro di compagnie). They continously renewed their partnership: Arte del Cambio 14. fols. 41r (1361), 43v (1362), 46r (1363), 48v (1364).

254 ASF, Arte del Cambio 14. fol. 53r. (1366).

255 See the tax declaration of Matteo's heirs, submitted in 1427: 'Madonna Piera, dona fu di messer Matteo de'avere per sua dota coll'agiunta fe messer Matteo fiorini 1000.' ASF, Catasto 59. fol. $875 \mathrm{v}$.

256 See Antonio's tax declaration, submitted in 1427: 'Una chasa possta nel populo di San Piero Maggiore al lato all Abergho alla Corona che da primo e secondo Giovanni Buonafe, da terzo via, da quarto sopradetto Antonio. Stavi a pigione Seraffo sarto [...] Una bottegha sotto la detta chasa con detto confini. Stavi a pigione Martino di Lionardo saponaio [...] E più ne tiene della detta chasa dietro Romanello aberghatore alla Corona [...] Una chasa al lato alla sopradetta chasa che da primo il detto Antonio, secondo Giovanni Buonafe, terzo Bernaro Ghuadangni, quarto via..' ASF, Catasto 56. fol. 47r. 
the two families were reinforced by another marriage in 1418 when Antonio took Caccia di Palmieri Altoviti's daughter, Matteo's niece, for his wife. ${ }^{257}$

The Infangati brothers' enterprises in Hungary exemplify the ways the Scolari brothers helped their relatives in acquiring business connections there. The Infangati brothers ventured to Hungary for the first time in the 1410 s, probably at the invitation of their in-laws. According to the testimony of Antonio's ledger, opened in 1417 upon their return to Florence, they had left Florence for Hungary together and consequently returned together as well. ${ }^{258}$ However, Baldinaccio, after a short period of time spent in Florence, decided to relocate to Hungary and settle in Andrea Scolari's court in Varadinum (Oradea, RO), where he stayed until the bishop's death. ${ }^{259}$ Antonio, instead, remained at home to run their businesses. Meanwhile in Hungary, Baldinaccio's textile workshop, which he operated with Matteo Scolari, might have provided him with some income. ${ }^{260}$ In the proximity of the workshop, located in Via Vaccareccia, he owned four other workshops, three of them rented by important goldsmiths of the time, who were engaged in entrepreneurial activity. ${ }^{261}$ The leading masters of these workshops, as we shall see in Chapter Five, were closely related to the Scolari. It might

257 'Ricordo come'io onore di Dio e della Vergine Madonna Santa Maria e di tutta la corte di Paradiso menai moglie la figliuola del Chaccia Altoviti a dì primo di magio 1418. Che al Dio ci dià grazia che noi viviamo in pace e chon onore e salvamento del'anima e del corpo.' ASF, Corp. Rel. Sopp. 97. 13. fol. 112r.

258 'Ricordanza chome io tornai d'Ungheria insino a dì xxii di marzo 1416 e viene con eso mecho Baldinaccio, mio fratello e tornossi indietro a dì d'aprile 1417 [...]'. ASF, Copr. Rel. Sopp. 97. 13. fol. 112r. (25/03/1417).

259 He was among the witnesses of the Bishop's testament. ASF, Corp. Rel. Sopp. 78. 326. fol. 291r. The close cooperation between the Bishop and the Infangati brothers is also illustrated by Andrea's deposit made in 1425, in favour of Antonio Infangati that he would pay taxes on his behalf. ASF, Monte ser. II. 2439. fol. 25 r.

26o Baldinaccio's business activity should have been sizeable, shown by the fact that after Matteo's death, his heirs were obliged to pay 640 florins to him. Part of the money, 500 Florentine florins, was left to him by Matteo's testament: ASF, Catasto 56 . fol. 493 r. He had not yet received the sum by 1431 . Catasto 385 . fol. 343 r. Sources do not explicitly refer to the type of textiles they produced. See Matteo's testament, made in 1424. ASF, NA 5814. fols. 271r-v.

261 See Baldinaccio's declaration, presented in 1427: 'Una botegha in Vacherecia nel popolo di Santa Cecilia, che da primo via, secondo Tomaso di Scholaio Ciachi, terzo via dietro, quarto lui medesimo. E detta botegha tiene a pigione Giovanni di Bandino orafo [...] Una botegha in detto popollo, da primo via, secondo rede di Jachopo di Latino de Pigli, terzo via dietro, quarto lui medesimo. E tiello a pigione Dino di Monte orafo [...] Una bottegha in detto popollo, da primo via, a secondo e terzo le rede di Jachopo di Latino de Pigli, quarto lui medesimo. E detta bottegha tiene a pigione Piero di Giovannino richamatore [...] Una botegha in detto popollo, da primo via, secondo Toso d'Albizo del Toso, terzo rede di Jachopo de Pigli, quarto lui medesimo. E detta botgeha tiene a pigione Michele di Sezi orafo [...]'. ASF, Catasto 56 . fol. 493 r. 
be that Baldinaccio and Matteo Scolari, thanks to the know-how of these masters, were also engaged in silk textile production in their workshop.

In 1424, it may have been his absence from Florence or his financial situation that forced Baldinaccio to repudiate his father. ${ }^{262}$ Either way, after 1426 his business expectations surely did not match the reality in Hungary; despite this, he decided to stay in Hungary even after the Scolaris' deaths. ${ }^{263}$ In 1431 , Antonio informs us in Baldinaccio's tax declaration that his brother's workshops were kept by the Commune for his unpaid taxes. ${ }^{264}$ Two years later, he referred to two of the workshops as his own, which suggests that he had actually paid his brother's debt in exchange for the ownership of the two places. At that point, Baldinaccio did not possess any other immovable properties in Florence. ${ }^{265}$

Besides Antonio, the other person in charge of Baldinaccio's businesses was Matteo Scolari's son-in-law, Francesco di Vieri Guadagni. In 1427, he submitted a tax return in Baldinaccio's absence. Six years later, in the second Catasto, Francesco noted that he was still obliged to pay him goo Florentine florins, which he might never have received, since Baldinaccio was detained in the King's prison. ${ }^{266}$ Following this brief notice, we have no more information on whether he was ever released. Meanwhile, Antonio continued to live in Florence at least until 1477, the date of the last entry in his account book. ${ }^{267}$

10

The Della Rena Family

The Della Rena were in-laws of the Infangati brothers, since sometime in the early 140os, when their second sister, Tommasa, married Piero di Bernardo della Rena. ${ }^{268}$ Even though Tommasa died early, her orphans secured Piero

262 ASF, Ripudie d'eredità 10. fol. 186v.

263 'Baldinaccio di Catellino Infanghati deto d'anni 32 incircha, e quello è in Ungheria e no' sapemo chome i fatti suoi lì pasano apparerne piùtosto malle [...]'. ASF, Catasto 56 . fol. 493r. 264 Baldinaccio's declaration, presented in 1431: '[...] Le dette botteghe tiene el Chomune per suoi chatasti e quelli che non à mai paghato nesuno [...]'. ASF, Catasto 385 . fol. 343 r.

265 Baldinaccio's declaration, submitted by his brother, in 1433: 'La persona sua è sostenuta ne paesi d'Ungheria già fa più tenpo e da llui non posso sapere niente [...]'. ASF, Catasto 478. fol. $463 \mathrm{r}$.

266 See Francesco Guadagni's declaration, which he presented in 1433: 'Antonio di Chatelino Infanghati e Baldinaccio suo fratello m'ànno a dare fiorini novecento i quali sono perduti per rispetto che Antonio c'è qui è chativo iscritto e Baldinaccio è in Ungheria in prigione [...]'. ASF, Catasto 478. fol. $772 \mathrm{v}$.

267 ASF, Corp. Rel. Sopp. 97. 13 .

268 The Infangati brothers, besides Piera, had two other sisters. One of them, Caterina, became nun in the monastery of San Francesco. Matteo extended his generosity even to her, by donating 
an alliance with the Infangati and through them an alliance with the Scolari. The Della Rena was a popolani family with earlier Ghibelline loyalties. They were originally from Certaldo and moved to Florence sometime before the end of the thirteenth century. In 1378, they had three households located in the golfalon of Chiavi, among them two in the Borgo San Pietro (Borgo degli Albizzi) and one in Via degli Albertinelli. ${ }^{269}$ In 1433 , they also had three households, composed of thirteen family members, located in the same Borgo. ${ }^{270}$ Out of the three households, one paid composto and the other two catasto in the value of seven florins, 36 soldi, and 20 denari. The total assets of the three households were 5018 Florentine florins. At the turn of the fifteenth century, the Della Rena were active members of the Por Santa Maria Guild as retail cloth merchants (ritagliatori) ${ }^{271}$ They also sporadically appear as speakers at the meetings of the secret councils; among them is Piero's father. ${ }^{272}$ Sources do not reveal any earlier connection which might have linked the family to the Kingdom of Hungary or to the Scolari family. Their case may illustrate eloquently that not only the Scolari but also their kin and in-laws brought their relatives to Hungary, a phenomenon which resulted in the highly endogamous nature of the local Florentine community.

\section{Piero di Bernardo della Rena (c. 1378/1380-1431): The In-Laws' In-Law}

Piero, therefore, was born into a family of a certain social status, even though they were neither powerful nor played an important role in the business life of the city. He might have been about a decade younger than the Scolari brothers, enough to be able to rely on their help at stages of his life. Following his father's footsteps in politics, Piero became an active, though

an annuity of 100 Florentine florins. 'Suora Caterina degli Altoviti de'avere fiorini 100, lasciò a sua vita, badessa in Santa Maria del Fiore, fiorini 10o.' ASF, Catasto 59. fol. $875 \mathrm{v}$.

269 Bernardo di Piero, Borgo San Pietro. ASF, Prestanze 369. fol. 75r. Geri di Doffo, Borgo San Pietro. Prestanze 369. fol. 75r. Corso di Piero, Via degli Albertinelli. Prestanze 369. fol. gor.

270 Antonio di Corso. ASF, Catasto 499. fol. 71v. Bernardo di Piero. Catasto 499. fol. 193v. Maso di Geri. Catasto 499. fol. 534r. The fourth declaration was submitted in the name of Niccolò di Corso's heirs. Catasto, 499. fol. 743r.

271 Corso di Piero della Rena, ritagliatore. ASF, Arte di Por Santa Maria 7. fol. 41r. (1404). Bartolomeo di Bernardo di Piero, fundacaio Arte di Por Santa Maria 7. fol. 45r. (1421) Baldinaccio di Piero di Bernardo. Arte di Por Santa Maria 7. fol. 45v. (1421) Gianozzo di Bernardo di Piero, ritagliatore. Arte di Por Santa Maria 7. fol. 8ov. (1405) Niccolò di Corso di Piero, ritagliatore. Arte di Por Santa Maria 7. fol. 143r. (1405) Two of them enrolled also in the Wool Guild. Baldinaccio di Piero di Bernardo. ASF, Arte della Lana 25. fol. 7v. (1408) Corso di Piero. Arte della Lana 25. fol. 11v. (1408).

272 Bernardo di Piero della Rena spoke two times between September 1390 and June 1404. ASF, CP 28. fol. 17or, CP 37. fol. 66r. 
not influential, member of the Florentine political elite. He enrolled in the Por Santa Maria Guild as a retail cloth merchant and later was elected once to guild consul. ${ }^{273} \mathrm{He}$ first covered a city office in 1407, which was followed by seven other occasions, among them the priorate twice. ${ }^{274}$ In the secret councils, he participated ten times as a speaker and, in 1418, he led a small embassy to Urbino. ${ }^{275}$

His ties to the Scolari were multiple, starting with their shared neighbourhood, through business, and then further social ties. ${ }^{276}$ In Matteo Scolari's absence from Florence, Piero acted as his legal representative. ${ }^{277} \mathrm{He}$ also received a minor share in the company founded by Matteo with Tommaso di Domenico Borghini and Antonio di Geri Bardi for the trade in Hungary. ${ }^{278}$ It is unclear if Piero ever travelled to Hungary, though this might have been one of the reasons his daughter was brought up in the Scolari palace.

Since his first wife, Tommasa Infangati, died early, leaving behind their small children, the help of his sister-in-law, Piera Infangati, was likely indispensable. However, Piero remarried sometime before 1427, taking for a wife Guglielmo Adimari's daughter, but his children with Tommasa secured him a life-long bond to the Scolari. ${ }^{279}$ Their daughter Sandra was taken in by her aunt and brought up with the Scolari girls in the neighbouring Scolari palace. ${ }^{280}$ She grew to become a family member, to the extent that Matteo, in his testament, left her a generous dowry of 500 Florentine florins. ${ }^{281}$ Thirty years later, her adopted sister, Francesca di Matteo Scolari,

273 ASF, Por Santa Maria 246. fol.15r. Por Santa Maria 7. fol. 162v (1414).

274 For his election to prior, see: Online Tratte of Office Holders, record n. 12269o, 122697.

275 For his speeches see: ASF, CP 39. fol. 166v (1409), CP 40. fol. 28r, CP 42. fol. 156v, CP 45. fol. 47r, CP 46. fols. 102v, 106v, 193r, CP 49. fols. 113r,116r, 117r. (1431) For the embassy see: ASF, Signori, Rapporti e relazioni di oratori fiorentini 2. fol. 54 r.

276 Bernardo kept a house in the Borgo degli Albizzi. See his tax declaration, submitted in 1433: ASF, Catasto 480. fol. 306r.

277 In 1413, Matteo made a deposit, which was managed by his wife and Piero della Rena. ASF, Monte ser. II. 1806. fol. 144V.

278 ASF, NA. 5814 fol. 3 or.

279 See Piero's tax return, which was submitted in 1427: 'Ghuiglielmo di Piero di Corso Adimari per resto della dota di monna Chaterina sua sirocchia e donna del detto Piero della Rena, de quali denari il detto Piero in sino a poi non à auto scritto niuno, fiorini 70o.' ASF, Catasto 59. fol. $646 \mathrm{r}$.

280 In 1427, Piera Infangati's tax declaration mentions the following: 'La Sandra, sua nipote che s'ela senpre tenuta è figliula di Piero della Rena e à promesso di maritalla tra di suo e de lascio le fa messer Matteo, d'anni 10.' ASF, Catasto 59. fol. 775v.

281 The tax declaration of the Scolaris' heirs refers to the donation: 'La Sandra, figliuola di Piero di Bernardo della Rena de'avere le lasciò fiorini 50o.' ASF, Catasto 59. fol. 875v. In 1424, Matteo left a certain sum for Sandra's dowry. ASF, NA 5814. fol. $32 \mathrm{v}$. 
even wished to bestow upon Sandra her entire patrimony. ${ }^{282}$ At the time of Piero della Rena's death in 1431, among his three children only Sandra had reached the legal age. ${ }^{283}$ Two years later, in 1433 , we hear about her marriage to Francesco Zati's son Antonio. ${ }^{284}$ The Zati was a triple-rooted merchant family, with connections in Florence, Venice, and the Kingdom of Hungary. Andrea's brother, Antonio, had worked earlier as an agent of the Carnesecchi-Fronte firm in Buda. Years later, he became officer of a minting chamber in Hungary. ${ }^{285}$ The marriage, therefore, would have been arranged well before Piero's death, maybe by Matteo Scolari himself, and it represented an advantageous social and economic bond in Florentine long-distance trade.

282 Francesca, at that time, was Tommaso di Neri Capponi's widow. ASF, Ginori Conti, serie Rinuccini 127. n. 4.

283 The children's declaration was submitted in 1431. ASF, Catasto 480 . fols. $306 \mathrm{r}-307 \mathrm{r}$.

284 ASF, Catasto 665. fol. 264 r.

285 Draskóczy, 'Olaszok a 15. századi Erdélyben'. See the balance of the Carnesecchi company, submitted in 1427: 'Antonio di Francesco Zati sta con noi a Buda [...]'. ASF, Catasto 28. fol. 10ogr. 
